\title{
Narrativas históricas: gravidade, sistemas de mundo e natureza da ciência $^{+*} 1$
}

Juliana M. Hidalgo F. Drummond ${ }^{2}$

Departamento de Física Teórica e Experimental - UFRN

José Diogo dos Santos Nicácio ${ }^{3}$

Mestrando em Ensino de Ciências Naturais e Matemática - UFRN

Arthur Winston Skeete Jr. ${ }^{4}$

Mestrando em Ensino de Ciências Naturais e Matemática - UFRN

Mykaell Martins da Silva ${ }^{5}$

Licenciado em Física e Bolsista do PIBID - UFRN

Amanda Thanize Araújo Câmara ${ }^{6}$

Licenciada em Física - UFRN

Francisco Valdécio Bezerra ${ }^{7}$

Bacharelando em Física

Natal - RN

\section{Resumo}

De acordo com o entendimento de que o ensinar ciência e o ensinar sobre a ciência não devem estar dissociados, apresenta-se um conjunto de narrativas históricas para utilização no Ensino Médio, tecendo considerações sobre os recortes históricos procedidos e as escolhas implementadas em sua elaboração. Procura-se chamar a atenção para as potenci-

\footnotetext{
${ }^{+}$Historical narratives: gravity, world systems and nature of science

* Recebido: julho de 2014. Aceito: outubro de 2014.

${ }^{1}$ Uma versão preliminar deste trabalho foi apresentada no XX SNEF (FERREIRA et al., 2013). Os autores agradecem aos pareceristas do CBEF pelos comentários e sugestões que contribuíram para a versão final do trabalho que ora se apresenta.

2 E-mail: julianahidalgo@dfte.ufrn.br

3 E-mail: diogonicacio@yahoo.com.br

4 E-mail: arthurwinston@hotmail.com

${ }^{5}$ E-mail: mykaell@dfte.ufrn.br

6 E-mail: amanda_thanize@yahoo.com.br

7 E-mail: valdecioml@yahoo.com.br
} 
alidades, possibilidades e limitações das narrativas. Esses pontos remetem explicitamente a reflexões relacionadas a uma utilização flexível, tendo em vista particularidades dos contextos educacionais.

Palavras-chave: Narrativas históricas; Gravidade; Sistemas de Mundo; Natureza da Ciência.

\begin{abstract}
According to the understanding that teaching scientific concepts and teaching about science should not be dissociated, a set of historical narratives used in the context of high school is presented in this work, expanding upon some considerations on the historical facts and implemented choices in their elaboration. The study also draws attention to the potentials, possibilities, and limitations of the narratives. These points refer explicitly to reflections related to a flexible use, considering the particularities of educational contexts.
\end{abstract}

Keywords: Historical Narratives; Gravity; Systems of the World; Nature of Science.

\title{
I. Introdução
}

Argumentos em defesa da importância da História e da Filosofia da Ciência (HFC) para o Ensino vêm de longa da data e costumam ser observados com frequência (ROBILOTTA, 1988; MATTHEWS, 1994; MATTHEWS, 1995; PEDUZZI, 2001; MARTINS, 2006a; LEDERMAN, 2012). Sugere-se a sua relevância para a contextualização de temas relacionados à Natureza da Ciência ( $\mathrm{NdC})$ : “[...] em qualquer nível, exemplos da história da ciência são úteis para gerar discussões sobre $\mathrm{NdC}$ e compreender sua natureza contextual" (CLOUGH; OLSON, 2008, p. 144).

A abordagem por meio de episódios históricos, de forma explícita e reflexiva, permite a problematização de certas visões "ingênuas" da ciência: a-problemática e a-histórica, individualista e elitista, acumulativa e de crescimento linear, indutivista e a-teórica (GIL PÉREZ et al., 2001). Estudiosos vêm se empenhando em elaborar e avaliar esse tipo de proposta (TEIXEIRA; EL-HANI; FREIRE JR, 2001; LEDERMAN, 2007; MCCOMAS, 2008; SILVA; MOURA, 2008; FORATO, 2009; MELLO; FIUZA; GUERRA, 2013; OLIVEIRA; GUERRA, 2013).

No âmbito da defesa da inserção da HFC no Ensino, inclui-se a consideração de que abordagens histórico-filosóficas favorecem a compreensão dos conceitos científicos e, num sentido mais extremo, situa-se a afirmação de que uma compreensão bem fundamentada seria 
necessariamente histórica (MATTHEWS, 1994, p. 50). A HFC seria fundamental para uma compreensão mais aprofundada dos conceitos, permitindo a localização dos mesmos nas tradições de pensamento. Caberia a ela não um papel acessório, introdutório ou complementar, mas sim essencial no contexto educacional, como elemento indissociável na tarefa de ensinar conceitos científicos.

A perspectiva de contemplar o equilíbrio entre processo e produto encontra ressonância na legislação educacional brasileira:

[...] é essencial que o conhecimento físico seja explicitado como um processo histórico, objeto de contínua transformação e associado às outras formas de expressão e produção humanas (BRASIL, 1999, p. 229).

A Física percebida enquanto construção histórica, como atividade social humana, emerge da cultura e leva à compreensão de que modelos explicativos não são únicos nem finais, tendo se sucedido ao longo dos tempos, [...]. O surgimento de teorias Físicas mantém uma relação complexa com o contexto social em que ocorreram (BRASIL, 1999, p. 235).

Tal perspectiva vem, há algum tempo, despertando uma recorrente ponderação: afinal, que História da Ciência ${ }^{8}$ seria adequada, tendo em vista os objetivos que se pretende atingir e os contextos nos quais se pretende inseri-la? (BIZZO, 1992; MATTHEWS, 1994). Aponta-se que o processo de elaboração de materiais e propostas didáticas deve envolver uma profunda reflexão tendo em vista a construção de uma História da Ciência que não seja do tipo pseudo-história, Whig ou anacrônica e que, ao mesmo tempo, seja apropriada ao contexto educacional (VIDEIRA, 2007; FORATO; MARTINS; PIETROCOLA, 2011).

Considerações significativas quanto aos desafios e obstáculos relacionados à transposição dos conteúdos especializados da História (e da Filosofia) da Ciência para a sala de aula sugerem a necessidade de lidar com questões de naturezas diversas (FORATO, 2009 ${ }^{9}$; HÖTTECKE; SILVA, 2010; FORATO; MARTINS; PIETROCOLA, 2012a e 2012b).

Fundamentais são a clareza quanto aos objetivos didáticos pretendidos e o possível papel da HFC nesse sentido. Definido o ponto de partida, na elaboração de propostas didáticas, precisam ser levados em conta aspectos como a realização de recortes históricos, a seleção de questões sobre a natureza do conhecimento científico e a atenção quanto ao nível de aprofundamento dos aspectos históricos e epistemológicos. Decisões importantes envolvem

\footnotetext{
${ }^{8}$ Ao nos referirmos à História da Ciência, nos remetemos também à Filosofia da Ciência, reconhecendo a relação de interdependência expressa por Lakatos: "A Filosofia da Ciência sem a História da Ciência é vazia; a História da Ciência sem a Filosofia da Ciência é cega” (1998, p. 21).

${ }^{9}$ Trata-se de uma contribuição relativamente recente e significativa sobre a transposição didática da História da Ciência com base nos referenciais propostos por Yves Chevallard.
} 
enfatizar aspectos científicos ou enfatizar fatores externos à ciência, utilizar ou não fontes primárias ${ }^{10}$ da História da Ciência.

É essencial formular atividades de ensino adequadas sob o ponto de vista pedagógico e epistemológico. Nesse sentido, o potencial das narrativas como recurso para o ensino de ciências, e, em particular, para a discussão de ideias sobre a Natureza da Ciência vem sendo destacado na literatura, como apontam Ribeiro e Martins (2007). Assim, uma opção recorrente em boa parte das propostas didáticas para a inserção da HFC no Ensino tem sido a elaboração e a utilização de textos do tipo narrativa histórica, isto é, textos histórico-pedagógicos. Essa característica foi observada em mapeamento recente do tipo "estado da arte" (TEIXEIRA; GRECA; FREIRE JR, 2012). Desse modo, dada à presença marcante desses materiais em iniciativas que buscam inserir conteúdos histórico-filosóficos no contexto escolar, justifica-se aqui a pertinência de refletir sobre esse tipo de recurso.

Na elaboração de narrativas histórico-pedagógicas, particularmente, aponta-se que diversos aspectos adicionais precisam ser avaliados: extensão e profundidade dos textos, quantidade de informações contempladas e formulação discursiva. É preciso, ainda, atentar para a falta de pré-requisitos dos alunos em relação aos conhecimentos físicos, históricos, epistemológicos e filosóficos, bem como, fundamentalmente, para lacunas na preparação do professor para a utilização desse tipo de material ${ }^{11}$.

À luz do entendimento de que o ensinar ciência e o ensinar sobre a ciência não devem estar dissociados, o presente artigo apresenta um conjunto de narrativas históricas (textos histórico-pedagógicos) para utilização no Ensino Médio, tecendo considerações sobre as escolhas realizadas em sua elaboração. Procura-se chamar a atenção para as potencialidades, bem como para as limitações do material elaborado, pontos que, ao longo do artigo, remetem explicitamente a reflexões relacionadas à utilização dos textos no contexto educacional.

Tomou-se como pilar para a elaboração dos textos, a proposta de uma compreensão mais aprofundada sobre o tema Gravidade a partir da sua fundamentação histórica. Essa compreensão perpassa o entendimento do contexto em que o conceito foi forjado, no âmbito das discussões sobre Sistema de Mundo, na chamada Revolução Científica, sinalizando continuidades e rupturas a partir de múltiplas contribuições antecedentes.

A introdução desses elementos no contexto educacional é intrinsecamente importante dada à relevância dos episódios históricos para o desenvolvimento científico ${ }^{12}$. Sustenta-se

\footnotetext{
${ }^{10}$ No contexto das discussões a respeito da inserção da HFC no Ensino notam-se expressões como "texto histórico", em referência a textos originais de pensadores e cientistas, e "narrativa histórica", em referência a textos elaborados para uso didático. Considerando que a semelhança entre essas expressões pode gerar equívocos, preferiu-se, aqui, utilizar a expressão "fontes primárias", de uso corrente entre os historiadores, em referência aos textos originais de pensadores e cientistas.

${ }^{11}$ A mediação do professor é um aspecto importante sinalizado por trabalhos que refletem sobre o potencial didático das narrativas (RIBEIRO; MARTINS, 2007).

${ }^{12}$ A esse respeito citamos argumentos de autores que figuram entre os mais citados em dissertações recentemente defendidas (ver mapeamento em VITAL; GUERRA, 2014): “[...] a História cultural da humanidade é, sem dúvi-
} 
aqui, adicionalmente, que a referida inserção pode contribuir para uma melhor compreensão desse importante conceito físico (Gravidade), bem como favorecer a abordagem explícita e contextualizada de discussões relacionadas à natureza do conhecimento científico.

Considera-se que as questões apontadas nas seções subsequentes sejam importantes para os que se dedicam à temática HFC no Ensino e vêm produzindo reflexões teóricas, elaborando subsídios e propostas didáticas, bem como efetivamente realizando avaliações empíricas de iniciativas. Conquanto que esses profissionais se veem de forma constante diante de desafios, as discussões podem contribuir para a reflexão sobre formas de superá-los ou contorná-los.

Em consonância com perspectivas atuais defende-se aqui, adicionalmente, que a viabilidade de implementação de abordagens histórico-filosóficas em sala de aula se relaciona à flexibilidade das propostas sugeridas:

Os professores precisam se sentir beneficiados com os novos materiais, [...], os materiais devem ser elaborados de modo flexível de forma a permitir que os professores os adaptem às suas condições atuais e locais (HÖTTECKE; SILVA, 2010, p. 17).

A flexibilidade, portanto, é uma característica que precisa ser observada pelos elaboradores de propostas para a inserção da HFC no Ensino. Esse aspecto, por sua vez, precisa ser compreendido e explorado pelo professor a fim de adaptar e reelaborar tais propostas frente ao seu próprio contexto, considerando, assim, seu importante papel na transposição didática da História da Ciência. Nesse sentido, as discussões sobre potencialidades, limitações e utilização flexível dos materiais são importantes para se alcançar o que a literatura vem apontando como o desenvolvimento de estratégias que tenham o apoio do professor (HÖTTECKE; SILVA, 2010). A possibilidade de adaptar um material a contextos particulares depende de se compreender de fato o que representa esse tipo de proposta e o quão flexível ela pode ser, o que se procura ressaltar no presente trabalho.

\section{Narrativas históricas sobre Gravidade, Sistemas de Mundo e Natureza da Ciência}

\section{II.1 Temática histórica, recortes e NdC}

Transpor para o contexto educacional o conhecimento aprofundado e especializado em História da Ciência implica enfrentar desafios e obstáculos (FORATO, 2009; HÖTTECKE; SILVA, 2010; FORATO; MARTINS; PIETROCOLA, 2012a e 2012b). Algumas particularidades tornam-se importantes no processo de elaboração de propostas didáticas

\footnotetext{
da, um dos pontos básicos de uma formação cultural mais ampla. Ela inclui a História da Arte (da pintura, da música, etc.), da Filosofia, as instituições, leis e costumes - e também a História da Ciência" (MARTINS, 1990, p. 3); "A História da ciência é intrinsecamente valorosa. Episódios importantes da história da ciência e da cultura [...] devem ser familiares a todos os estudantes" (MATTHEWS, 1994, p. 50).
} 
que objetivam tratar sobre Natureza da Ciência de modo contextualizado, por meio de episódios históricos. Nessas circunstâncias, entrelaçam-se as escolhas da temática histórica, das questões sobre a natureza do conhecimento científico e dos aspectos a enfatizar nos episódios históricos selecionados. Essas opções dependem de objetivos didáticos e contextos educacionais particulares para os quais as propostas se dirigem.

No presente caso, optou-se pela temática Gravidade e Sistemas de Mundo. A opção é justificável dada à potencialidade para a elaboração de textos histórico-pedagógicos direcionados para o Ensino Médio, que objetivem mostrar o processo de unificação envolvido no desenvolvimento desses conhecimentos como um aspecto importante relacionado à natureza do empreendimento científico ${ }^{13}$.

Essa escolha deliberada vai de encontro a uma visão deformada, "exclusivamente analítica" da ciência: "[...] a desvalorização e mesmo o esquecimento dos processos de unificação como característica fundamental da evolução dos conhecimentos científicos" (GIL PÉREZ et al., 2001, p. 132).

Procurou-se, mais especificamente, contribuir para o preenchimento de uma importante lacuna que se manifesta na (quase) omissão no contexto educacional da "unificação que supõe a síntese newtoniana das mecânicas celeste e terrestre, [...]. A integração de dois universos considerados essencialmente diferentes, derrubando a suposta barreira entre o mundo celeste e o sublunar [...]" (GIL PÉREZ et al., 2001, p. 132-134) ${ }^{14}$.

Nesse sentido, tencionou-se elaborar narrativas históricas que transparecessem o entendimento de que as mudanças de concepção acerca da Gravidade, na Revolução Científica, estiveram relacionadas a um panorama de mudanças de Sistema de Mundo, do Geocêntrico para o Heliocêntrico, e se relacionaram à unificação das Físicas sub e supralunar, no contexto da síntese newtoniana. Buscou-se materializar essa compreensão ao longo dos textos "Laçadas no céu", "Heliocentrismo versus Geocentrismo" e "Uma nova proposta sobre a Gravidade", os quais são apresentados na íntegra em apêndice ao final do presente artigo.

Particularmente, um conjunto de textos relacionados à História da Astronomia inspirou os autores a escreverem as narrativas e podem ser muito úteis aos professores como fonte de consulta e aprofundamento acerca da referida temática histórica (MARTINS, 1994; LOPES, 2001; COPÉRNICO, 2003; FORATO, 2006; MARTINS, 2006b; SILVEIRA; PEDUZZI, 2006; FERREIRA, 2009; DANIEL, 2011) ${ }^{15}$.

\footnotetext{
13 Os autores referem-se ao contexto educacional do Ensino Médio, "particular", nesse sentido, enquanto "nível de escolaridade visado", e a objetivos didáticos "particulares" de contemplar determinadas discussões relacionadas à temática Natureza da Ciência. Propostas de utilização dos textos devem ser adaptadas a realidades escolares específicas.

${ }^{14}$ Como registra a literatura, existe grave lacuna em materiais didáticos quanto à questão da unificação. As iniciativas de trazer à tona tal discussão são ainda pontuais. Citam-se, como exemplos, BRAGA et al, 1999 e PEDUZZI, 2008.

Há outros textos de apoio dos quais os professores podem se beneficiar, tais como: WESTFALL, 2003 e FREIRE JR; MATOS FILHO; DO VALLE, 2004.
} 
O necessário recorte histórico implicou a seleção dos seguintes conteúdos: a concepção aristotélica de Gravidade como propriedade dos corpos graves; a compreensão da queda dos corpos no contexto do Geocentrismo; o uso do "argumento da torre" na Antiguidade como evidência a favor da imobilidade da Terra; a retomada do "argumento da torre" e do fenômeno da queda dos corpos no contexto do debate Heliocentrismo versus Geocentrismo; a interpretação newtoniana para a Gravidade, antecedentes e aspectos do seu desenvolvimento, a unificação da Física.

Como essa relação de conteúdos indica, a síntese newtoniana não foi prontamente apresentada ao estudante-leitor como mera afirmação, conhecimento pronto, acabado. Em contraposição a uma visão a-problemática e a-histórica da ciência (GIL PÉREZ et al., 2001), tratou-se, por outro lado, de trazer à tona discussões que envolveram a referida síntese. Buscou-se construir a compreensão de um processo ao longo dos textos, os quais apontam explicitamente a relevância da síntese:

Então, sua conclusão foi que todos os corpos se atraíam segundo essa relação. A chamada "Gravitação Universal” abriu caminho para a consolidação de uma Física unificada. [Texto "Uma nova proposta sobre a Gravidade”].

Além da oposição a uma visão exclusivamente analítica da ciência, procurou-se ir de encontro a outras visões deformadas de ciência: a visão a-problemática e a-histórica, a visão individualista e elitista, a visão acumulativa de crescimento linear e a visão indutivista e ateórica da ciência (GIL PÉREZ et al., 2001). Por meio da articulação dos conteúdos históricos selecionados, tencionou-se ao longo dos textos enfatizar de modo explícito e contextualizado, tal como vêm sendo recomendado pela literatura, algumas questões relacionadas à natureza do conhecimento científico: a cooperação na ciência, a dependência das observações em relação a pressupostos teóricos, a possibilidade de desacordo entre os pesquisadores e a provisoriedade do conhecimento (MCCOMAS; ALMAZROA; CLOUGH, 1998) ${ }^{16}$.

\section{II.2 Formulação discursiva e aprofundamento dos episódios}

Ainda no que concerne aos desafios inerentes à transposição da História da Ciência para o contexto educacional, outros aspectos foram observados na elaboração das narrativas históricas. Vem se chamando a atenção para a necessidade de elaborar propostas didáticas com formulações discursivas adequadas aos níveis de escolaridade aos quais as mesmas se destinam. Acrescenta-se, ainda, o cuidado quanto ao nível de aprofundamento dos episódios históricos, bem como a atenção quanto à existência de conteúdos históricos que não são de

\footnotetext{
${ }^{16}$ Essa escolha não implica perder de vista ressalvas importantes. Como bem ratificam Bagdonas e Silva (2013, p. 216), não há uma visão única adequada sobre a natureza da ciência: a "natureza da ciência é complexa e dinâmica". Seria um contrassenso criticar uma visão rígida e algorítmica da ciência e, ao mesmo tempo, adotar listagens de mensagens sobre a natureza da ciência como um novo currículo a ser ensinado nas aulas de ciências. Por outro lado, como afirmam os autores, posturas extremas como o empirismo-indutivismo deveriam ser problematizadas.
} 
fácil compreensão. Refletir sobre como inserir determinados conteúdos históricos no contexto educacional depende, inclusive, de particularidades inerentes à própria temática histórica focalizada (FORATO; MARTINS; PIETROCOLA, 2012a).

À luz desses apontamentos, considerou-se na elaboração dos textos históricopedagógicos que, apesar do recorte criterioso, ainda assim os conteúdos históricos selecionados eram complexos. Procurou-se enfrentar possíveis dificuldades quanto à temática e aos conteúdos históricos. Os textos foram interligados, com a introdução cautelosa e progressiva de questões e argumentos, retomados ao longo das narrativas. Considerando como usual a não familiaridade dos estudantes em relação aos temas abordados, a opção pela retomada de elementos centrais, tencionou estabelecer oportunidades para que os leitores os compreendessem.

Intitulou-se "Laçadas no céu" o primeiro texto histórico-pedagógico elaborado, em alusão aos movimentos dos planetas observados pelos gregos na Antiguidade. O texto apresenta a interpretação aristotélica para a Gravidade como propriedade dos corpos graves, que buscavam o seu lugar natural, o centro do universo, o qual coincidia com o centro da Terra. Essa interpretação estava relacionada ao sistema Geocêntrico, o qual, por sua vez, implicava a existência de duas Físicas, uma sub e outra supralunar ${ }^{17}$.

A caracterização das duas Físicas foi limitada, tendo em vista parâmetros que balizaram o nível de aprofundamento dos textos: o contexto educacional ao qual se dirigem, bem como os objetivos da proposta. Escolheu-se justamente ressaltar poucos elementos específicos, sendo esses essenciais para a compreensão da relevância da posterior unificação da Física: havia uma Física para o mundo sublunar, caraterizado por transformações e formado pelos elementos terra, ar, fogo e água, e uma Física para o mundo supralunar, caracterizado pela constância e formado pelo éter.

Com a referência inicial nesse primeiro texto à existência de duas Físicas, tencionouse, que, posteriormente, ao longo das demais leituras, o leitor compreendesse a importância das mudanças de interpretação acerca da Gravidade na Revolução Científica. Apresentou-se, desse modo, uma informação retomada explicitamente no terceiro texto, quando a proposta de uma nova interpretação para a Gravidade, por Isaac Newton, relacionou-se à unificação da Física no sentido de um entendimento conjunto de fenômenos terrestres e celestes.

\footnotetext{
${ }^{17}$ Mais precisamente, o sistema aristotélico-ptolomaico era geostático, mas não geocêntrico. A narrativa "Laçadas no céu" contém a ressalva de que o sistema não era exatamente geocêntrico. Assim, o uso do termo "geocêntrico" refere-se a uma aproximação. Na versão inicial da narrativa apresentada no XX SNEF, essa ressalva não existia (FERREIRA et al., 2013). Naquela ocasião, decidiu-se não incluir esse detalhamento. Julgou-se melhor omiti-lo por receio de acréscimo de complexidade à narrativa, bem como por considerar que o mesmo não seria fundamental para o entendimento das rupturas no conceito de Gravidade. É uma decisão possível, embora desconfortável, tendo em vista a falha quanto à precisão histórica. Assim, considerou-se importante e oportuna a indicação do parecerista do CBEF de que a ressalva seria significativa para mostrar a sofisticação do modelo ptolomaico, indicando que as ideias do passado não são mais simples que as do presente. Levando em conta esse ponto de vista, o qual deve ser compartilhado também por outros leitores, introduziu-se na narrativa breve comentário, buscando preservar o nível de complexidade da mesma. Aos professores que desejarem mais informações quanto a esse aspecto recomenda-se a consulta às referências listadas.
} 
Ainda quanto à apresentação progressiva das questões, no primeiro texto, considerou-se importante trazer para o estudante-leitor alguns elementos que, posteriormente, na época da Revolução Científica, seriam fundamentais no debate acerca da mudança de sistema de Geocêntrico para Heliocêntrico. Apresentou-se, por exemplo, o argumento da torre, como evidência recorrente na Antiguidade a favor da imobilidade da Terra.

De acordo com a intenção de produzir textos interligados, o propósito dessa alusão inicial não foi discutir a validade desse argumento, mas sim apenas torná-lo familiar ao estudante enquanto evidência favorável a uma Terra imóvel no contexto Geocêntrico. Retomou-se o "argumento da torre" nos textos seguintes.

A segunda narrativa histórica, intitulada "Heliocentrismo versus Geocentrismo", retomou a queda dos corpos graves e a concepção aristotélica de Gravidade como componentes científicos relacionados ao Geocentrismo. Em seguida, a narrativa trouxe à tona a proposta Heliocêntrica de Nicolau Copérnico, no século XVI. Indicou que a mesma havia sido motivada por questões teóricas e era tão complexa quanto à de Ptolomeu. Reforçou, ainda, os problemas suscitados na época por essa proposta. Copérnico deixou lacunas que seriam objeto de pesquisa para Galileu Galilei.

Já o terceiro texto, "Uma nova proposta sobre a Gravidade", relembrou, logo em seu início, questões enfrentadas pelos heliocentristas, reunindo elementos já citados nos dois textos anteriores: o "argumento da torre", a necessidade de uma nova compreensão para a Gravidade e dificuldades com o possível fim da divisão do mundo em sublunar e supralunar (que até então justificava a existência de "duas Físicas"). O resgate desses elementos foi motivado pelo objetivo de relacionar a unificação das Físicas sub e supralunar à nova interpretação para a Gravidade sugerida Isaac Newton.

Como demonstram os comentários anteriores, a complexidade da temática histórica abordada pelos textos foi contrabalançada pelos cuidados com a formulação discursiva e com o nível de aprofundamento dos episódios históricos, tendo em vista a inteligibilidade dos mesmos. Foram omitidas informações técnicas detalhadas sobre os sistemas de mundo Geocêntrico e Heliocêntrico. Evitou-se, deliberadamente, que os estudantes desviassem a atenção do foco central dos textos: questionamentos específicos levassem à reflexão.

Utilizou-se linguagem coloquial, acessível, a fim de facilitar a interlocução com os estudantes-leitores. Ainda buscando a interlocução, os textos elaborados mostraram pesquisadores em situações caracterizadas por elementos vivenciados pelos próprios alunos. Assim, procurou-se humanizar o pesquisador, mostrando que o mesmo faz perguntas, hesita, muda de ideia, tem dúvidas sobre o que está investigando:

O pensador inglês Isaac Newton estava inserido nesse contexto de rejeição à Gravidade aristotélica. Newton aceitava a nova explicação proposta por Descartes para a Gravidade quando, ainda jovem, resolver estudar mais sobre esse assunto. Depois de muitas leituras, estudos e reflexões, acabou mudando de ideia. 
[...] Newton pode ter pensado... se a Gravidade diminui com a altura, até onde será que ela chega? Será que ela chega até a Lua? [Texto "Uma nova proposta sobre a Gravidade"]

Importante ressaltar que as passagens foram elaboradas de forma que as perguntas sinalizassem possíveis problemas ou assuntos que podem ter sido tratados pelos pesquisadores. As perguntas colaboram para que o estudante compreenda melhor as propostas apresentadas. Por outro lado, a redação das narrativas procura não indicar que eles de fato fizeram especificamente tais perguntas. Ainda assim, para evitar uma compreensão equivocada a esse respeito, a mediação do professor pode ser importante.

Priorizando o diálogo ${ }^{18}$, os textos apresentaram problemas e questões importantes, sobre as quais os leitores-alunos foram convidados a refletir opinando sobre o desenvolvimento de uma ciência, cujo dinamismo foi ressaltado: "O que será que aconteceu depois [de Aristóteles]? Será que aceitamos esse modelo hoje?”.

Em passagem de um dos textos, ressaltou-se que na Revolução Científica a aceitação do sistema Heliocêntrico era problemática, pois implicava a rejeição da diferença entre sublunar e supralunar, base do conhecimento físico então existente. A questão complexa, apresentada em um texto, foi retomada no texto seguinte, o qual inseriu os leitores diante de uma pergunta importante:

O sistema Heliocêntrico podia acabar com a diferença entre sublunar e supralunar. Isso criaria um problemão para a Ciência da época: o que fazer com as duas Físicas que existiam? Lembrando o que vimos no texto passado, havia, então, uma Física para o mundo sublunar e outra para o supralunar... [Texto "Heliocentrismo versus Geocentrismo"]

Os textos elaborados podem ser utilizados em sala de aula de forma a se contraporem a uma perspectiva que vem sendo criticada no ensino científico: "a apresentação de conhecimentos previamente elaborados, sem dar oportunidade aos estudantes de contactarem e explorarem atividades na perspectiva de um ensino do tipo investigativo" (GIL PÉREZ et al., 2001, p. 126). Nesse sentido, seria recomendável uma problematização inicial que buscasse levantar questões e hipóteses acerca da temática em foco, seguida de leitura conjunta dos textos, na qual o professor atuasse como mediador na investigação das questões previamente levantadas, registrando as manifestações dos alunos, conduzindo de forma aberta e dialogada à compreensão do processo histórico e do conhecimento científico em foco.

Ao longo da problematização que se sobressai no material elaborado, definições formais de expressões possivelmente desconhecidas pelos estudantes, como "pressupostos teóricos", não são oferecidas diretamente. Pretendeu-se que os contextos de utilização dessas expressões nos textos, bem como a recorrência das mesmas em diversas passagens, pudessem

\footnotetext{
${ }^{18}$ De acordo com DOLL Jr (1997 apud RIBEIRO; MARTINS, 2007, p. 294), a narrativa deve propor ao leitor o desafio da interpretação, trazendo indeterminação adequada e suficiente para levar o leitor ao diálogo.
} 
esclarecê-las. Exemplifica-se a contextualização desse tipo de expressão por meio do seguinte trecho:

Propuseram vários tipos de modelos para tentar conciliar seus pressupostos teóricos (planetas devem percorrer círculos) ao que pareciam observar (planetas fazem laçadas no céu). [Texto "Laçadas no céu"]

Privilegiou-se, assim, certa autonomia do estudante-leitor, embora se considere que a leitura compartilhada do texto, mediada pelo professor, seja recomendável dada à complexidade das discussões sobre a natureza do conhecimento científico. Nas subseções ulteriores, mostra-se como a abordagem explícita e contextualizada dessas questões foi realizada ao longo das narrativas.

\section{II.3 Contraposição a visões ingênuas da ciência}

Mencionou-se anteriormente que os textos elaborados se opõem a uma visão exclusivamente analítica da ciência, trazendo à tona o processo de unificação da Física relacionado ao desenvolvimento do conceito de Gravidade. Na presente seção, procura-se mostrar como, por meio dos episódios históricos, os textos enfatizam outros aspectos relacionados à natureza do conhecimento científico (MCCOMAS; ALMAZROA; CLOUGH, 1998) que contrastam com visões ingênuas da ciência (GIL PÉREZ et al., 2001; KOSMINSKY; GIORDAN, 2002).

As referidas concepções inadequadas não são independentes, autônomas, mas sim, formam um esquema conceitual relativamente integrado: o conhecimento científico acumularse-ia por meio de descobertas individuais, realizadas sem dificuldade por cientistas geniais, agindo de modo neutro e imparcial (CHALMERS, 1993). Pesquisas demonstram esse padrão de coerência, isto é, a associação de visões deformadas entre si (DRIVER; OLDHAM, 1986). Tendo em vista tais circunstâncias, adota-se a opção de problematizar essas visões de modo integrado nas narrativas.

\section{Visões a-problemática, a-histórica, acumulativa e de crescimento linear}

De acordo com Gil Pérez e colaboradores (2001), o ensino de ciências reforçaria uma concepção a-problemática e a-histórica da ciência ao transmitir:

[...] os conhecimentos já elaborados, sem mostrar os problemas que lhe deram origem, qual foi a sua evolução, as dificuldades encontradas etc., e não dando igualmente a conhecer as limitações do conhecimento científico atual nem as perspectivas que, entretanto, se abrem. [...] o que dificulta a captação, bem como a compreensão da racionalidade de todo o processo e empreendimento científicos (p. 131).

Contrapondo-se a uma visão a-problemática e a-histórica da ciência, ressalta-se, de modo frequente e explícito nas narrativas elaboradas, a laboriosa busca de soluções para problemas como uma característica importante do trabalho dos estudiosos: 
Observar esse movimento tão estranho dos planetas podia ser um problema para certos pensadores dependendo do contexto cultural do qual participavam. Alguns consideravam que os astros eram perfeitos e deveriam ter movimentos perfeitos, ou seja, circulares. [...]. Uma das soluções encontradas foi usar uma composição de círculos que, em conjunto, "produziam" as laçadas e explicavam o movimento de cada planeta visto da Terra. [Texto "Laçadas no céu”]

Vimos no texto passado que os copernicanos (heliocentristas) tiveram alguns problemas para enfrentar. O "argumento da torre" foi um deles. [Texto "Uma nova proposta sobre a Gravidade"]

O sistema Heliocêntrico podia, então, acabar com a diferença entre sublunar e supralunar. Isso criaria um problemão para a Ciência da época: o que fazer com as duas Físicas que existiam? [Texto "Heliocentrismo versus Geocentrismo"]

As narrativas destacam o enfrentamento de dificuldades pelos pesquisadores. Citam, por exemplo, problemas acarretados pela proposta de Nicolau Copérnico que precisariam ser respondidos:

Copérnico morreu no mesmo ano em que suas ideias foram publicadas, e várias questões foram surgindo... Como explicar a queda dos corpos? Se para Aristóteles eles caíam porque buscavam o centro do universo onde estava a Terra... e quando se propunha tirar a Terra do centro, colocando o Sol nesse lugar? Por que os corpos caíam para a Terra e não para o Sol?

Explicar a "queda dos corpos" tornou-se um problema para quem defendia o heliocentrismo. Aliás, quem gostou do sistema de Copérnico tinha que lidar ainda com muitos outros problemas. Um deles era o "argumento da torre". [Texto "Heliocentrismo versus Geocentrismo"]

Os textos, em oposição à perspectiva de introduzir conhecimentos prontos, encaminham o estudante-leitor para a discussão dos assuntos. Por exemplo, em relação ao problema da "queda dos corpos", traz-se à tona a célebre discussão de Galileu a respeito dos fenômenos observados na cabine de um navio:

Foi, então, com muito estudo do que outros haviam dito que Galileu concluiu que a pedra cairia no pé da torre em qualquer situação: tanto se a Terra estivesse parada ou em movimento. Para convencer as pessoas sobre isso, ele lembrou o seguinte: se estamos na cabine fechada de um navio gotas d'água pingam dentro de um vaso da mesma forma quer o barco esteja em movimento ou parado. Ele citou muitos fenômenos para mostrar que qualquer coisa que ocorra na cabine não nos permite dizer se o navio está ou não em movimento. 
O recado de Galileu era o seguinte: o "argumento da torre" não mostra que a Terra está parada; era possível sim aceitar o sistema Heliocêntrico, no qual a Terra estava em movimento. [Texto "Heliocentrismo versus Geocentrismo"]

Enfatiza-se, assim, o empenho dos personagens históricos em resolver questões, destacando o envolvimento dos mesmos em discussões que se relacionaram ao desenvolvimento do conceito de Gravidade e à unificação da Física. Tenciona-se, nas narrativas, transmitir uma visão de ciência "viva", dinâmica, marcada por controvérsias, debates em torno de questões e assuntos que movem (e muitas vezes dividem) a comunidade científica:

Como dá para perceber havia, então, na época de Galileu uma briga feia entre copernicanos (heliocentristas) e aristotélicos (geocentristas). [Texto "Heliocentrismo versus Geocentrismo"]

Em consonância com o objetivo de apresentar exemplares que permitam problematizar visões ingênuas de ciência, as alusões a problemas e busca de soluções ressaltam não somente os confrontos entre teorias rivais, como também as rupturas que as interpretações propostas podem ocasionar na ciência.

O que Newton estava dizendo representava uma mudança muito grande no modo como se compreendia a Gravidade. Ela não era mais uma propriedade do corpo. Passava a ser, então, uma força que agia a distância sobre um corpo. [...]

O astrônomo Johannes Kepler havia percebido que o sistema de Copérnico com as órbitas circulares não dava muito certo. As trajetórias dos planetas não podiam ser explicadas assim. Kepler propôs, então, que as órbitas fossem elípticas, com o Sol em um dos focos. [Texto "Uma nova proposta sobre a Gravidade"].

No primeiro parágrafo desse trecho, a expressão uma "mudança muito grande" sinaliza exemplo de ruptura profunda, a qual pode ser percebida pelo aluno, sobretudo com a mediação do professor. Nesse sentido, a atuação do professor é fundamental para que o estudante compreenda que Newton não estava "acrescentando" algo sobre a gravidade, mas sim propondo uma remodelação profunda. No segundo parágrafo do trecho transcrito da mesma narrativa outra ruptura importante transparece.

Procura-se evitar, assim, a visão de que a ciência se constitui pela acumulação de conhecimentos de forma linear. Essa visão inadequada (e pouco reconhecida pelos professores, segundo investigações empíricas) ignora "as crises e as remodelações profundas [...] não se referindo às frequentes confrontações entre teorias rivais, às controvérsias científicas, nem aos complexos processos de mudança” (GIL PÉREZ et al., 2001, p. 132-133).

Os três textos foram construídos de modo a evitar a visão acumulativa e de crescimento linear, explorando a disputa e a dramaticidade das mudanças de interpretações acerca de assuntos que se relacionaram à temática em foco. Deve-se destacar, ainda, que é inerente a esse tipo de construção deixar transparecer o caráter provisório, mutável do conhecimento 
científico. A importância dessa característica da ciência motiva a sua alusão explícita em alguns trechos dos textos elaborados.

Mas ... o que será que aconteceu depois? Será que aceitamos esse modelo hoje? E a Física... existem duas? É assim ou mudou? [Texto "Laçadas no céu"]

[...]Aristóteles dividia o mundo em sublunar, onde tudo era imperfeito e mudava, e supralunar, onde tudo era perfeito e constante. Mas, a astronomia dos séculos XVI e XVII parecia sugerir que isso não era bem assim. [Texto "Heliocentrismo versus Geocentrismo"]

O pensador inglês Isaac Newton estava inserido nesse contexto de rejeição à Gravidade aristotélica. Newton aceitava a nova explicação proposta por Descartes para a Gravidade quando, ainda jovem, resolver estudar mais sobre esse assunto. Depois de muitas leituras, estudos e reflexões, acabou mudando de ideia. [Texto "Uma nova proposta sobre a Gravidade"]

Os trechos citados apontam tanto a possibilidade de mudanças em interpretações aceitas pela coletividade, bem como indicam ainda que mesmo um pesquisador pode rever suas próprias ideias. A transitoriedade transparece, portanto, de forma relacionada ao intrínseco caráter humano da ciência.

\section{Visão individualista e elitista}

A elaboração das narrativas históricas levou em conta a necessidade de ressaltar a ciência como atividade de cooperação. A importância de conhecimentos científicos já existentes para o desenvolvimento de novas ideias pode ser ilustrada por diversas passagens, como as que descrevem a elaboração de uma proposta para a Gravidade por Isaac Newton.

Sinaliza-se a relevância da temática Gravidade na época de Newton. Como indica citação transcrita em seção anterior do presente trabalho, destacam-se elementos significativos para a proposta desse pesquisador: sua aceitação inicial da concepção de Descartes para a Gravidade, segundo a qual os corpos eram empurrados para a Terra por uma correnteza de éter. Também são citados (possíveis) questionamentos decorrentes da proposta de Francis Bacon, segundo a qual a Gravidade diminuía com a altura.

Com base nessa proposta, Newton pode ter pensado... se a Gravidade diminui com a altura, até onde será que ela chega? Será que ela chega até a Lua? [Texto "Uma nova proposta sobre a Gravidade"]

Enfatiza-se que, para Isaac Newton, teriam sido importantes também os estudos de Descartes sobre o movimento circular de uma pedra, amarrada num cordão, que não escapava da sua trajetória devido ao puxão dado pelo indivíduo que o segurava. Isso o ajudaria a pensar, por analogia, que algo mantinha o movimento da Lua em torno da Terra: 
Se a Lua se movia em torno da Terra, algo deveria manter a Lua nessa trajetória, sem deixar que ela escapasse ... Era como se a Lua fosse escapar da sua trajetória, mas algo sempre a puxasse em direção a Terra, mantendo o seu movimento. [...]

Newton usou os resultados dos estudos de Descartes. Newton pensou que a força da Gravidade agia à distância sobre a Lua, tal como a mão da pessoa que puxava a pedra amarrada. [Texto "Uma nova proposta sobre a Gravidade"].

Reforçando o empenho dos pesquisadores, procura-se mostrar que em meio a muitos esforços e cálculos, Newton interpretou que uma força, a "Gravidade", atraía para a Terra uma maçã solta no ar. E essa força era justamente o que mantinha a Lua em seu movimento, atraindo-a para a Terra, fazendo-a sempre "cair" em direção a essa, sem sair pela tangente à sua trajetória. Newton calculou que uma força para manter tal condição deveria ser proporcional ao inverso do quadrado da distância entre os corpos envolvidos na situação (MARTINS, 2006b).

Os textos elaborados procuram, ainda, evidenciar que problemas propostos por um pesquisador podem estimular o interesse de outros, o que também reforça a visão de que a ciência é uma atividade de cooperação. Cita-se, por exemplo, que Johannes Kepler, ao propor que os planetas tivessem órbitas elípticas (e não circulares, como havia sugerido Copérnico), deixou em aberto uma questão: que tipo de força poderia manter os planetas nesse tipo de trajetória? Estudando a questão, Newton chegou à conclusão de que uma força atrativa entre o Sol e o planeta, proporcional ao inverso do quadrado da distância entre eles, daria esse tipo de resultado. Essa conclusão estaria no bojo do enunciado da chamada "Gravitação Universal", segundo a qual todos os corpos se atraem de acordo com essa mesma relação, o que constituiria um aspecto importante da síntese newtoniana (MARTINS, 2006b).

Vários outros trechos foram elaborados de modo a deixarem transparecer o trabalho coletivo dos pesquisadores, rompendo, assim, com uma visão individualista da ciência.

\footnotetext{
Foi, então, com muito estudo do que outros haviam dito que Galileu concluiu que a pedra cairia no pé da torre em qualquer situação: tanto se a Terra estivesse parada ou em movimento. [Texto "Heliocentrismo versus Geocentrismo"].
}

Em sala de aula, esses trechos nos quais a mensagem acerca da cooperação está implícita, podem ser explorados pelo professor para enfatizar o caráter colaborativo da ciência, conduzindo problematização acerca de possíveis visões individualistas.

Dada a complexidade e a pouca familiaridade do estudante-leitor com a temática $\mathrm{NdC}$, bem como o contraste entre o que se procura abordar nos textos e o que se concebe como visão popular de ciência, considerou-se que seria importante que tais mensagens fossem reforçadas ao longo dos textos, em passagens que ora as trouxessem de modo implícito, ora de modo explícito. Há, portanto, ao longo das narrativas históricas, trechos que afirmam explicitamente a cooperação como característica da ciência. As passagens transcritas a seguir repre- 
sentam exemplares de contraposição contextualizada e explícita a uma visão individualista da ciência:

Quem resolveu esse problema? Galileu Galilei era adepto do sistema de Copérnico e resolveu colaborar para a solução desse problema. Precisou da ajuda de muitos pensadores... Sem as ideias do próprio Aristóteles, de muitos pesquisadores da Idade Média e de seus contemporâneos, ele possivelmente não chegaria a lugar algum. Ciência não se faz sozinho, nem de uma hora para outra. [Texto "Heliocentrismo versus Geocentrismo"].

Dá para perceber, assim, que todo esse conhecimento não dependeu somente de uma pessoa e não apareceu de repente, mas sim com muito estudo e cooperação. Achar que uma maçã caiu na cabeça de alguém e aí tudo foi entendido por ele, sozinho, rapidamente... não dá, não é? [Texto "Uma nova proposta sobre a Gravidade"].

Ao longo dos textos, ao evidenciar a ciência como empreendimento coletivo, procura-se ressaltar ainda que essa cooperação se estabelece inclusive por meio de uma característica essencial da ciência: o desacordo entre pesquisadores. Ilustra-se a possibilidade de discordância em várias passagens:

[...] Aristóteles concluiu que ela estava no centro do universo [...]. Nicolau Copérnico propôs um sistema de mundo Heliocêntrico, isto é, com o Sol no centro do universo. [Texto "Heliocentrismo versus Geocentrismo"].

Como vimos, na Antiguidade, considerava-se que a Gravidade era uma propriedade dos corpos graves. Eles buscavam o centro do universo, no qual estava a Terra. Não eram atraídos por ela.

Quase dois mil anos depois de Aristóteles, René Descartes, um pensador francês adepto do heliocentrismo, propôs outra explicação. Para Descartes, os corpos caíam porque eram empurrados em direção a Terra por uma correnteza de um elemento invisível, o éter. Isso foi no século XVII. Havia, portanto, certo contexto de questionamento à visão de Gravidade como propriedade de um corpo. [Texto "Uma nova proposta sobre a Gravidade"].

Vamos a dois exemplos importantes que sugeriam mudanças e imperfeições também no mundo supralunar. Dentre muitas outras contribuições suas importantes, o astrônomo Tycho Brahe realizou observações a olho nu e notou que estrelas mudavam. Podiam nascer e morrer. Com o telescópio, Galileu obteve imagens que interpretou como crateras e montanhas na Lua e manchas no Sol. Mas nem todo mundo aceitava o uso do telescópio e havia motivo para isso. Nem se sabia muito bem como ele funcionava. Quem sabe o instrumento moderno não estava criando deformações que não existiam? Essa hipótese foi mesmo cogitada na época. 
De qualquer forma, o que Galileu e Brahe diziam abalava o que então era aceito: talvez o mundo supralunar não fosse tão perfeito nem tão constante quanto Aristóteles pensava. [Texto "Heliocentrismo versus Geocentrismo"] 19.

O astrônomo Johannes Kepler havia percebido que o sistema de Copérnico com as órbitas circulares não dava muito certo. As trajetórias dos planetas não podiam ser explicadas assim. [Texto "Uma nova proposta sobre a Gravidade"].

Essas passagens podem ser exploradas pelo professor também no intuito de problematizar visões indutivistas e a-teóricas da ciência, como aponta a seção seguinte.

\section{Visão indutivista e a-teórica}

Em estreita relação com a característica possibilidade de desacordo entre os pesquisadores, enfatiza-se nos textos que os fenômenos naturais podem ser interpretados de diversas maneiras. "Gravidade" foi ora entendida como propriedade dos corpos graves, ora segundo uma perspectiva baseada em colisões entre partículas, ora como uma força de interação entre os corpos. Ressalta-se que ao longo da História da Ciência, existiram várias descrições para o fenômeno da queda dos corpos: os corpos (graves) caíam porque buscavam o seu lugar natural, caíam porque eram empurrados por uma correnteza de éter, caíam porque eram atraídos pela Terra.

O uso do termo "interpretações" remete a uma preocupação expressa em diversas passagens: mostrar a ciência como tentativa de descrever fenômenos naturais, sendo criativa na invenção de conceitos e explicações.

Há muito tempo atrás, na Antiguidade, pensadores gregos propunham explicações para fenômenos da natureza. As explicações podiam ser distintas e até mesmo a forma de produzir conhecimento podia variar de acordo com a corrente filosófica da qual participavam. [...].

Fizeram longas observações do céu, registrando as posições das estrelas pacientemente noite após noite. Perceberam, então, estrelas que ficavam fixas, formando desenhos permanentes no céu. Algumas outras estrelas mudavam de posição ao longo do ano, como se vagassem em meio aos desenhos. Chamaram essas outras estrelas de "planetas", o que significa "errante". Esse movimento visto da Terra podia ser mesmo muito estranho. [Texto "Laçadas no céu"].

A criatividade, o caráter interpretativo da ciência e a possibilidade de desacordo se relacionam a outros aspectos relacionados à natureza do conhecimento científico contempla-

\footnotetext{
${ }^{19}$ Na narrativa, a referência a uma única contribuição específica, dentre as muitas realizadas por Tycho Brahe, se justifica tendo em vista o argumento desenvolvido onde a mesma se insere (mudanças no mundo supralunar estrelas sofrem mudanças). Sendo assim, uma contribuição específica é resgatada para justificar o argumento exposto. Com base nas referências bibliográficas recomendadas, o professor pode trazer à tona outros aspectos das contribuições do astrônomo, caso julgue conveniente.
} 
dos nos textos. Hipóteses orientam a investigação, de modo que as observações são relacionadas a pressupostos teóricos. A abordagem a essa concepção foi explícita, por exemplo, na alusão às tentativas gregas de conceber modelos que "salvassem" os movimentos irregulares dos planetas no céu:

Alguns consideravam que os astros eram perfeitos e deveriam ter movimentos perfeitos, ou seja, circulares. Isso porque, para eles, o círculo era a forma perfeita, sem início, nem fim. [...] para eles, então, os planetas não poderiam ter movimentos esquisitos como laçadas, embora fosse isso o que viam da Terra. O que fazer então? [...]. Propuseram vários tipos de modelos para tentar conciliar seus pressupostos teóricos (planetas devem percorrer círculos) ao que pareciam observar (planetas fazem laçadas no céu). [Texto "Laçadas no céu"] ${ }^{20}$.

Outras passagens dos textos são implícitas quanto à alusão a essa mensagem sobre a natureza do conhecimento científico, e podem ser utilizadas pelo professor para ilustrá-la em intervenção didática:

A motivação de Copérnico era pensar que se o Sol era "fonte da vida" deveria ficar no centro. Em seguida, viriam Mercúrio, Vênus, Terra, Marte, Júpiter e Saturno. Manteve os planetas em órbitas circulares, seguindo o mesmo ideal de perfeição dos gregos [Texto "Heliocentrismo versus Geocentrismo"].

Eles caíam porque buscavam o centro do universo. Então, como os corpos caíam para a Terra, Aristóteles concluiu que ela estava no centro do universo [Texto "Heliocentrismo versus Geocentrismo"].

Essas passagens, em conjunto, contrastam diretamente com uma concepção empírico-indutivista e a-teórica da ciência, a qual enfatiza “o papel 'neutro' da observação e da experimentação (não influenciadas por ideias apriorísticas), esquecendo o papel essencial das hipóteses como orientadoras da investigação, assim como dos corpos coerentes de conhecimentos (teorias) disponíveis, que orientam todo o processo" (GIL PÉREZ et al., 2001, p.129).

Tal visão tem peso importante no contexto educacional, o qual costuma transmitir concepções empiristas indutivistas, difundidas em materiais didáticos. Essas concepções são frequentes também em propagandas, na divulgação científica e nos meios de comunicação em geral. Costuma-se ressaltar a ideia da "descoberta científica", realizada pelo cientista que "ouve o que a natureza tem a dizer", observando-a de forma neutra, desprovida de pressupostos. Estudantes (e professores) estão, portanto, em contato frequente com visões indutivistas e

\footnotetext{
${ }^{20}$ Essa passagem pode ser usada para contextualizar a concepção de que a ciência é parte das tradições culturais e sociais.
} 
a-teóricas da ciência (LEDERMAN, 1992; CHALMERS, 1993; HARRES, 1999; BATISTA; MOHR; FERRARI, 2007; PAGLIARINI; SILVA, 2007; CLOUGH; OLSON, 2008).

Tendo em vista esse contexto, justifica-se a intenção de que as narrativas elaboradas possam suscitar oportunidades recorrentes de problematização a visões ingênuas que concebem os conhecimentos como resultados da inferência indutiva a partir de "dados puros". Por isso, diversos fatos históricos relacionados à temática Gravidade foram utilizados para contextualizar a dependência da observação em relação a pressupostos teóricos, oferecendo múltiplos momentos de reflexão.

\section{II.4 Lembrando a atual historiografia ${ }^{21}$ da ciência}

As visões sustentadas pela historiografia da ciência das últimas décadas têm sido ressaltadas em textos de natureza teórica sobre a inserção da HFC no ensino. Segundo Forato, Martins e Pietrocola (2012, p. 126): “A elaboração de narrativas históricas e os aspectos epistemológicos que elas transmitem podem ser avaliados e orientados pela historiografia atual da História da Ciência".

Apesar de reconhecida relevância para o contexto educacional, essas considerações pouco têm se materializado em materiais didáticos e na prática educacional (PAGLIARINI; SILVA, 2006; BATISTA; MOHR; FERRARI, 2007; PENA; TEIXEIRA, 2013). Costuma-se observar "um uso banal da História da Ciência", a "redução da história da ciência a nomes, datas e anedotas":

\section{[...] Uma falsa concepção, baseada em ideias como: \\ - a ciência é feita por grandes personagens; \\ - a ciência é constituída a partir de eventos ou episódios marcantes, que são as "descobertas" realizadas pelos cientistas; \\ - cada alteração da ciência ocorre em uma data determinada; \\ - cada fato independe dos demais e pode ser estudado isoladamente (MARTINS, 2006a, p. 9).}

Esse tipo de História da Ciência ainda frequente no contexto educacional remonta aos trabalhos que os historiadores da ciência profissionais costumavam produzir há cerca de cem anos. Na década de 1920, produzia-se uma História da Ciência linear, progressiva, caracterizada por um grande número de nomes e datas. Os historiadores descreviam as grandes descobertas realizadas pelos grandes gênios, concebidos como seres neutros, imparciais, alheios à sociedade. Faziam o que chamamos de "hagiografia", uma descrição das virtudes heroicas e grandes realizações das personagens da ciência. Tinham um olhar anacrônico em relação aos episódios históricos. Descreviam os fatos do passado com base no que aceitavam

\footnotetext{
${ }^{21}$ Emprega-se o termo historiografia de acordo com a definição: “A historiografia [...] é o produto primário da atividade dos historiadores. Ela é constituída essencialmente por textos escritos. Ela reflete sobre os acontecimentos históricos, mas agrega-lhe um caráter discursivo novo. Ela procura desvendar aspectos da história, mas não é uma mera descrição da realidade histórica” (MARTINS, 2005, p. 115).
} 
como ciência. Aquilo que não se parecia com a ciência que conheciam era julgado como primitivo ou mesmo errado. Buscavam os pais, os precursores da ciência que conheciam. Faziam o que ficou conhecido como História Whig, Pedigree (ALFONSO-GOLDFARB, 1994; MARTINS, 2001).

Da década de 1920 até hoje, a área de pesquisa História da Ciência mudou muito. Essa maneira de escrever a História da Ciência foi profundamente questionada. Atualmente, a História da Ciência pode ser definida como o estudo das expressões de conhecimento sobre a natureza de modo contextualizado. Considera-se que cada cultura, cada comunidade científica e cada época tem seus objetivos, formas de ver o mundo, e critérios de verdade que regem sua ciência. Questionando a postura anacrônica, a ciência atual deixou de ser padrão de comparação. A História da Ciência não é mais um conjunto de datas e informações biográficas sobre os grandes gênios. Considera-se inadequado falar em pais e precursores da ciência.

Em consonância com esse panorama, as narrativas históricas elaboradas e discutidas no presente trabalho levam em conta critérios que se relacionam ao que é a História da Ciência atualmente, como os cuidados em relação ao anacronismo e a comparações que implicam juízos de valor ${ }^{22}$. Por outro lado, é importante destacar, como aponta a literatura, que um obstáculo significativo à inserção da HFC no contexto educacional vem sendo justamente a falta de preparação do professor frente a esse gênero de questões:

\section{[...] compensar a falta de preparo do professor para lidar com saberes da HFC na sala de aula inclui prepará-lo para identificar e problematizar manifestações ana- crônicas. Materiais didáticos poderiam incluir orientações e advertências sobre i- deias inesperadas e possíveis modos para se lidar com elas (FORATO; MARTINS; PIETROCOLA, 2012, p. 148).}

Tendo em vista esse contexto, portanto, considerou-se importante, na presente seção, trazer à tona reflexões que indiquem explicitamente como as narrativas elaboradas buscam contemplar perspectivas historiográficas atuais.

Um exemplo pode ser acompanhado no texto "Laçadas no céu". Em sua redação, há a intenção deliberada de superar o modo como, em materiais didáticos, as ideias de Aristóteles costumam ser apresentadas (quando o são), quer seja, como concepções ingênuas, "primitivas". Em perspectiva oposta, deixa-se transparecer que a concepção aristotélica de Gravidade era bastante sofisticada. Sinaliza-se que a mesma estava inserida num corpo coerente de

\footnotetext{
${ }^{22}$ Um texto conciso e interessante sobre o significado do termo "anacronismo" pode ser consultado em http://www.brasilescola.com/historia/anacronismo.htm (Acesso em 11 jul. 2014). Reproduz-se a seguir um recorte desse texto: "O anacronismo ou anticronismo consiste basicamente em utilizar os conceitos e ideias de uma época para analisar os fatos de outro tempo. Em outras palavras, o anacronismo é uma forma equivocada onde tentamos avaliar um determinado tempo histórico à luz de valores que não pertencem a esse mesmo tempo histórico. Por mais que isso pareça um erro banal ou facilmente perceptível, devemos estar atentos sobre como o anacronismo interfere no nosso estudo da História. [...] Ao contrário do que possa parecer, esse problema não só atinge os profissionais da História, mas também é encontrado no dia a dia das salas de aula. De forma geral, muitos alunos costumam tecer comentários sobre o passado com base nos seus próprios valores”.
} 
conhecimentos, sendo relacionada ao sistema Geocêntrico, o qual, por sua vez, implicava a existência de duas Físicas complexas, uma sub e outra supralunar.

Procura-se enfrentar o desafio de tentar trazer para o ambiente escolar de forma adequada, em termos de conteúdo, nível de aprofundamento e linguagem, aspectos que deixem transparecer a complexidade do conhecimento aristotélico, os quais se relacionam a sua importância e caráter perene na História da Ciência. Ainda que tais aspectos não possam ser aprofundados, busca-se, assim, a contraposição à concepção anacrônica de que os pesquisadores do passado eram tolos e propunham conhecimentos banais.

Enfrentando um dilema recorrente na transposição didática da História da Ciência, muitos pensadores não tão conhecidos, mas também relevantes, poderiam ser citados nas narrativas e não o foram, a fim de que as mesmas não se tornassem extensas ou por demais complexas. Por outro lado, face ao potencial risco de assim se aproximar de posturas hagiográficas, considerou-se conveniente frisar que sem os contextos antecedentes e da época, sem os estudos de muitos personagens anônimos, as contribuições citadas não existiriam. Em consonância com perspectivas historiográficas recentes indica-se que a "ciência não brota pronta, na cabeça de "grandes gênios"” (MARTINS, 2006a, p. 2) ${ }^{23}$.

Deliberadamente, evitam-se nas narrativas elaboradas informações biográficas minuciosas a respeito dos personagens citados. Adota-se tal procedimento a fim de coibir um possível tom apologético, bem como no sentido de evitar que os estudantes desviem a atenção do foco central dos textos: questionamentos que levem à reflexão. Igualmente por esse último motivo, evitam-se indicações exaustivas de datas, o que também colabora para afastar a visão de que "descobertas na ciência ocorrem em datas pontuais". As referências cronológicas são cautelosas e ocorrem exclusivamente em caso de relevância para os objetivos pretendidos. Por exemplo, a fim de aproximar a discussão do contexto do leitor e situar no tempo a importância do modelo Geocêntrico, afirma-se, no segundo texto, que o mesmo era o mais aceito quando os portugueses chegaram ao Brasil, em 1500.

Ademais de refletirem a observância a critérios da historiografia atual, as narrativas histórico-pedagógicas elaboradas contemplam a preocupação de transpor para o contexto educacional interpretações que vêm sendo propostas em pesquisas sobre a História da Ciência. Citam-se a seguir alguns exemplos, os quais, como se pode notar, se articulam também a discussões atuais sobre a Natureza da Ciência.

As narrativas ressaltam que o tema "queda dos corpos" vinha sendo estudado desde a Antiguidade, que o termo "Gravidade" já existia na época de Isaac Newton, e que ele se esforçou muito estudando um assunto então importante, tomando como base as discussões e ideias de vários pesquisadores de sua época, bem como de períodos remotos. Nas narrativas busca-se, explicitamente, desfazer o mito de que a simples queda de uma maçã em sua cabeça

\footnotetext{
${ }^{23}$ Observa-se ao longo da História da Ciência: “[...] a contribuição titânica de alguns cientistas, acompanhada, no entanto, por muitos erros gigantescos das mesmas pessoas; o papel de uma multidão de pesquisadores obscuros no desenvolvimento de importantes aspectos das ciências" (MARTINS, 2006a, p.4).
} 
teria feito Newton descobrir a Gravidade (MARTINS, 2006b). Ressalta-se que ao reinterpretar o fenômeno da queda dos corpos, Newton adotou a concepção de uma força agindo à distância. Essa concepção, incomum na ciência da época, era aceita pela alquimia, de onde Newton a teria tomado emprestada (FORATO, 2006). Contemplando revisões recentes da História da Ciência, ressalta-se no texto histórico-pedagógico a importância dos conhecimentos alquímicos de Isaac Newton para o que atualmente se considera como Física.

Outras passagens dos textos elaborados refletem ainda a preocupação de contemplar interpretações relevantes para o contexto educacional, sobretudo no que se refere à desconstrução de visões empiristas-indutivistas (SILVEIRA; PEDUZZI, 2006; DANIEL, 2011). Ressalta-se, assim, o caráter essencial de determinados elementos teóricos para as contribuições científicas de Copérnico: motivações pitagóricas (Sol como fonte da vida, papel central) e ideal grego de perfeição (movimentos dos planetas, perfeitos, circulares). Ainda no que diz respeito às contribuições de Copérnico, procura-se desfazer visões equivocadas comuns, anacrônicas, de que ele teria sido motivado por observações astronômicas realizadas com novos instrumentos, como os telescópios ${ }^{24}$. Em contraposição, ressalta-se que ele viveu em período anterior ao uso do aparelho. À luz de determinados pressupostos teóricos, ele reinterpretou informações observacionais muito precisas e já contempladas pelo sistema Geocêntrico na época (COPÉRNICO, 2003).

Outros pontos foram enfatizados ainda no que diz respeito a desfazer visões simplistas, usualmente disseminadas acerca dos fatos históricos citados: as descobertas observacionais da astronomia na época não finalizaram de modo crucial o embate entre o Heliocentrismo e o Geocentrismo. Crateras na lua, manchas solares e supernovas não foram "evidências irrefutáveis" a favor do sistema copernicano. Escreve-se, no texto "Heliocentrismo versus Geocentrismo", que esses elementos sugeriam que o mundo supralunar não era perfeito, o que "podia até ajudar quem preferia o sistema Heliocêntrico...", mas, por outro lado, procura-se indicar que essas "evidências" foram motivo de questionamentos científicos razoáveis e passíveis de diversas interpretações na época (FERREIRA, 2009).

Como se pode notar, os aspectos citados nessa seção aproximam as narrativas histórico-pedagógicas de perspectivas historiográficas recentes. Refletir sobre esses aspectos é importante, tendo em vista que os mesmos costumam ser desconhecidos por professores da Educação Básica, sendo essa lacuna um franco passaporte para a propagação de visões ingênuas sobre a ciência.

\section{5 Simplificações e omissões}

As pesquisas especializadas em História da Ciência são realizadas pelos historiadores da ciência a partir de estudo aprofundado de fontes primárias e secundárias. Textos elabo-

\footnotetext{
${ }^{24}$ Essa visão também remete ao empirismo-indutivismo, tendo em vista que concebe a observação como origem do conhecimento.
} 
rados por esses profissionais costumam ser detalhados e geralmente não visam a propósitos pedagógicos.

Na transposição para o contexto educacional, merece destaque a necessidade de simplificações e omissões a partir da historiografia da ciência. Elaborar narrativas didáticas de cunho histórico-filosófico para o Ensino Médio é um desafio qualquer que seja a temática escolhida (FORATO, 2009). Selecionar e omitir conteúdos, pensar em como inseri-los depende de particularidades da temática histórica em si, do contexto educacional para o qual se dirige a proposta didática e dos seus objetivos específicos.

No presente caso, foram realizadas opções difíceis ante destacada riqueza. Poder-seia, por exemplo, apresentar de modo mais detalhado o sistema aristotélico-ptolomaico e as Físicas aristotélicas (sub e supralunar). As narrativas deixam de lado grande parte da sofisticação dessas ideias (detalhes sobre os equantes, movimentos naturais, violentos, etc.), limitando-se ao essencial tendo em vista os objetivos da proposta, cujo foco central é a temática da Gravidade e a unificação das Físicas sub e supralunar.

Foram escolhidos basicamente os seguintes conteúdos históricos: a Gravidade aristotélica como propriedade dos corpos graves, a queda dos corpos no contexto Geocêntrico; o "argumento da torre" na Antiguidade como evidência da imobilidade da Terra; o "argumento da torre" e o fenômeno da queda dos corpos no debate Heliocentrismo versus Geocentrismo; a Gravidade newtoniana, aspectos do seu desenvolvimento e importância para a unificação da Física.

Justificou-se o recorte tendo em vista a elaboração de três textos didáticos interligados, curtos, com conteúdos e linguagem apropriados ao contexto do Ensino Médio. Levou-se em conta a necessidade de apresentar episódios históricos que pudessem contextualizar as discussões específicas sobre a natureza do conhecimento científico. Foram necessárias omissões e simplificações. Caso contrário, haveria sobrecarga de informações e complexidade excessiva que tornariam o material inadequado para o contexto e propósitos almejados. Embora necessários, esses procedimentos envolveram assumir riscos, dentre os quais se situam os apontados a seguir.

O tipo de sistema proposto do Aristóteles já era importante para antecessores do filósofo. Aristóteles trabalhou a partir de um modelo de esferas concêntricas, sugerido pelo pensador Eudoxo, discípulo de Platão (LOPES, 2001). Nesse modelo, de cunho essencialmente matemático, para descrever o movimento de um planeta eram necessárias várias esferas concêntricas com eixos de rotação distintos. Preocupado com aspectos físicos, Aristóteles propôs aumentar o número de esferas concêntricas, introduzindo esferas intermediárias a fim de que o movimento de um planeta não interferisse no movimento de outro.

As narrativas histórico-pedagógicas apresentam o sistema Geocêntrico de Aristóteles sem que sejam introduzidos detalhes relevantes sobre o próprio sistema e sua origem. Ocultam-se elementos que sinalizariam a cooperação como importante aspecto da natureza da ciência. Face às simplificações e omissões realizadas, corre-se o risco de transmitir a impres- 
são equivocada de que Aristóteles foi o primeiro a propor um sistema Geocêntrico e que este utilizava órbitas, o que significaria incorrer em anacronismo.

Em princípio, os professores que desejarem utilizar as narrativas em sala de aula precisariam estar conscientes quanto a esses riscos, pois assim poderiam contornar possíveis dificuldades. O mesmo pode ser dito no tocante à potencialidade de que outras visões inadequadas sejam transmitidas.

O texto "Laçadas no céu" apresenta aspectos da Física aristotélica, elaborada no século IV a.C., e, em seguida, o texto "Heliocentrismo versus Geocentrismo" aprofunda esses aspectos e sustenta que essa Física se relacionava ao sistema aristotélico-ptolomaico aceito no início dos anos de 1500. Esse "salto", isto é, a omissão de contribuições para a Física durante todos os séculos que separam Aristóteles de Galileu Galilei, pode passar a impressão de que nada foi feito acerca desses assuntos no longo período em questão.

Conquanto que em certo trecho específico desse último texto a existência de contribuições científicas nesse período transpareça quando se afirma que Galileu recorreu a ideias “de muitos pesquisadores da Idade Média e de seus contemporâneos", essa passagem pode ser insuficiente para evitar a visão equivocada sugerida pela lacuna supracitada. E, adicionalmente, a passagem citada não colabora para que se perceba que muitas dessas contribuições medievais representaram contraposições significativas à Física aristotélica. Esta não permaneceu incólume ao longo dos séculos.

Como se pode notar, para efetivamente contemplar tais questões e evitar interpretações equivocadas, grande complexidade precisaria ser adicionada às narrativas. Preferiu-se correr tal risco, sendo, por isso, fundamental frisar a necessidade de que o professor esteja consciente quanto a essas limitações, atento e apto a atuar no sentido de esclarecer possíveis dificuldades.

Outras omissões e suas plausíveis decorrências devem ainda ser consideradas. As narrativas históricas citam as contribuições de Tycho Brahe, mas não contemplam a informação de que o astrônomo propôs um sistema de mundo misto entre o Geocêntrico e o Heliocêntrico, conservando a Terra central e planetas se movendo ao redor do Sol. Essa informação foi omitida a fim de não tornar o texto ainda mais complexo, já que citá-la implicaria ter que justificar a proposta de Brahe, bem como a sua rejeição. No entanto, citar o astrônomo em meio à discussão sobre a relevância dos argumentos observacionais do século XVII para a aceitação do sistema copernicano pode transmitir a impressão equivocada de que o próprio Brahe aceitava um sistema aos moldes de Copérnico.

Evitou-se a sobrecarga de informações também no que diz respeito a outros episódios históricos. Sobre a Antiguidade, aponta-se que o "sistema Geocêntrico foi bem aceito". Essa afirmação implicitamente sugere que sua aceitação não foi unânime e deixa espaço para se pensar que houve sugestões alternativas ao Geocentrismo. De fato, a proposta Heliocêntrica de Aristarco existiu na Antiguidade (LOPES, 2001). Aristarco era contemporâneo de Aristóteles e poderia ter sido citado na segunda narrativa histórica elaborada, inclusive para indi- 
car que Copérnico não foi o primeiro a propor algo nesse sentido. No entanto, optou-se por não citar o modelo Heliocêntrico de Aristarco. Assim, por um lado, evitaram-se explicações acerca da sua rejeição na Antiguidade. E, por outro, suprimiu-se a decorrente necessidade de explicitar o que então havia mudado na época de Copérnico e abria caminho para a aceitação desse tipo de modelo. Observa-se que essas explicações deixariam os textos ainda mais complexos, desviando-os dos seus objetivos centrais.

A mesma diretriz foi seguida em outras circunstâncias. Em relação à queda dos corpos, o foco das narrativas é essencialmente a compreensão do que seria a Gravidade. Por isso, deliberadamente, são apresentados aspectos do pensamento aristotélico que dizem respeito a "por quê os corpos caem". Não são apresentados aspectos relacionados a "como os corpos caem" (a concepção de que os corpos caem com velocidades constantes, por exemplo). Esses aspectos, por um lado, desviariam os textos dos seus objetivos centrais e, por outro, demandariam considerações adicionais sobre contribuições a respeito desses tópicos em outros períodos históricos.

De modo geral, os riscos apontados na presente seção foram levados em conta na elaboração das narrativas, mas ainda assim julgou-se que as omissões e simplificações assinaladas constituíam um procedimento necessário a fim de evitar que os textos se tornassem desfocados, complexos e extensos, inadequados ao contexto educacional a que se destinavam. Diante dessas limitações, considera-se que não somente as potencialidades das narrativas, mas também as suas fragilidades precisam ser conhecidas pelo professor que deseja aplicá-las em sala de aula. Nesse sentido, frente a concepções equivocadas fomentadas pela própria incompletude dos textos, a atuação do professor torna-se fundamental. E, para isso, recorrer a leituras de aprofundamento sobre a temática histórica é um requisito importantes profissionais que se proponham a utilizar as narrativas em sala de aula.

\section{Considerações adicionais sobre a utilização dos textos ${ }^{25}$}

Abordagens histórico-filosóficas podem ter papel significativo para a compreensão de temas físicos, materializando a perspectiva prevista na legislação de que "o conhecimento

\footnotetext{
${ }^{25}$ Como se mencionou anteriormente, a proposta do presente artigo é, fundamentalmente, apresentar o conjunto de narrativas históricas para utilização no Ensino Médio, destacando recortes e escolhas realizadas em sua elaboração, potencialidades e possibilidades dos textos. Na presente seção, tecem-se considerações adicionais sobre a utilização dos textos, para as quais colaborou reflexão acerca de intervenção em escola pública do Ensino Médio, vinculada ao subprojeto Física do PIBID-UFRN, na cidade de Natal (RN). Embora não seja o foco do presente artigo relatar detalhadamente tal experiência, é importante salientar que os textos (segundo redação em versão preliminar apresentada no XX SNEF; ver FERREIRA et al., 2013) foram aplicados em realidade escolar. $\mathrm{Na}$ ocasião, os bolsistas de iniciação à docência atuaram como mediadores em atividade de leitura e discussão em classe. A intervenção englobou problematização acerca de visões sobre a natureza da ciência e do conceito de gravidade. Maquetes elaboradas pelos bolsistas foram utilizadas para representar sistemas de mundo geocêntrico e heliocêntrico. Ao final da intervenção, em atividade criativa de elaboração de histórias em quadrinhos nas quais registraram suas impressões, os estudantes do Ensino Médio manifestaram interesse significativo pelos episódios e temática abordada.
} 
físico seja explicitado como um processo histórico, objeto de contínua transformação" (BRASIL, 1999, p. 229).

As narrativas históricas apresentadas relacionam a mudança de concepção acerca da Gravidade, na chamada Revolução Científica, a um panorama de mudança de Sistema de Mundo e à unificação das Físicas sub e supralunares. Em consonância com visões historiográficas atuais (cuja relevância para o contexto educacional tem sido destacada), procura-se conectar a construção dos conceitos científicos a seres humanos, estudiosos de outras épocas que se preocuparam com seus próprios problemas, tinham dúvidas, enfrentaram os caminhos difíceis da investigação científica usando mecanismos próprios aos seus contextos para resolver os desafios que se apresentaram.

Ao explicitar essa perspectiva ao longo dos textos, incentiva-se a reflexão do estudante, buscando a interlocução por meio de formulação discursiva adequada, a qual prioriza certa autonomia do leitor. Adicionalmente, como vêm destacando reflexões sobre o potencial das narrativas como recurso didático (RIBEIRO, MARTINS, 2007) deve-se ressaltar que o papel do professor é fundamental na utilização desse tipo de material no contexto educacional.

Em princípio, os textos podem colaborar para que os alunos compreendam uma multiplicidade de aspectos relacionados aos conceitos físicos em questão: a existência de diferentes visões sobre Gravidade; a Gravidade aristotélica no contexto do geocentrismo; a Gravidade cartesiana e newtoniana no contexto do heliocentrismo; os sistemas Heliocêntrico e Geocêntrico; os argumentos favoráveis a esses sistemas em diferentes períodos históricos; as dificuldades de aceitação do modelo Heliocêntrico, identificando a mudança de sistema de mundo como um lento processo de ruptura; a unificação das Físicas sub e supralunar, sua relação com o sistema de mundo Heliocêntrico e a Gravitação newtoniana, etc.

Os episódios históricos foram tomados como circunstâncias de contextualização para questões relacionadas à natureza do conhecimento científico: a cooperação na ciência, a dependência das observações em relação a pressupostos teóricos, a possibilidade de desacordo entre os pesquisadores e a provisoriedade do conhecimento. A contraposição a visões ingênuas de ciência (exclusivamente analítica, a-problemática e a-histórica, individualista e elitista, acumulativa de crescimento linear, indutivista e a-teórica) é estabelecida de forma recorrente ao longo dos textos, seja de forma implícita ou explícita, considerando o caráter complexo dessas questões.

A seleção e ênfase desses aspectos nas discussões cabem ao professor. Prevê-se que a utilização dos textos sobre Sistema de Mundo seja flexível de modo que o educador pode escolher não enfatizar a discussão de determinadas questões, priorizando outras. As discussões relacionadas à natureza da ciência podem ou não constituir foco de uma intervenção didática. Ainda que o sejam, as potencialidades das narrativas nesse sentido específico podem não ser exploradas em sua totalidade. Ao educador, portanto, cabem decisões refletidas importantes: observar as potencialidades dos textos, definir objetivos para uma possível inter- 
venção didática e como a mesma será conduzida, definir a forma de leitura (em grupo, individualmente, em aula, previamente), etc. Essas escolhas dependem de elementos relacionados ao contexto educacional. O tempo didático, por exemplo, é um fator importante que deve ser levado em conta pelo professor, diante de um material flexível, adaptável ao seu contexto.

Em sala de aula, a condução de problematização anterior ao contato dos estudantes com os textos pode ser importante para a sensibilização quanto às questões abordadas, servindo de estímulo à participação criativa nas discussões:

- Os pesquisadores trabalham de modo isolado, realizando descobertas? Dependem do que outros pesquisadores fizeram/ fazem?

- Os pesquisadores discordam entre si? Os fenômenos falam por si mesmo ou são interpretados?

- O que os pesquisadores pensam quando estão investigando os assuntos? Será que enfrentam dificuldades?

- No caso da queda dos corpos, será que as pessoas começaram a investigar esse assunto há muito tempo?

- Você já deve ter ouvido a palavra Gravidade... O que significa?

- Será que o termo Gravidade surgiu há muito tempo? Será que ele teve sempre o mesmo significado?

A condução de atividade com os textos na forma de uma discussão aberta pode ser interessante. O professor, atuando como mediador, pode chamar a atenção para aspectos (que julgar) importantes, promovendo a reflexão e esclarecendo passagens duvidosas. Pode estimular que os próprios alunos formulem perguntas que possam levar a observações e reflexões. Pode incentivar a participação, solicitando que comentem sobre o que pensam ao longo da leitura 26 :

- O que chama a sua atenção na leitura? Identifique detalhes que ache importantes.

- O que você nota que não esperava? O que você nota que não sabe explicar?

- Por que os pesquisadores se interessavam por aqueles assuntos? Pareciam considerar importante o que estavam fazendo? Por quê?

- O que estavam fazendo/discutindo? Como agiam os pesquisadores citados nesse texto?

- Onde estavam? Em que época? Será que o comportamento dos pesquisadores hoje é diferente?

É importante observar que as posturas e questões exemplificadas anteriormente decorrem de escolhas que são prerrogativas do professor.

\footnotetext{
${ }^{26}$ Os questionamentos listados foram inspirados pelo projeto "Teaching with primary sources quarterly", desenvolvido pela Library of Congress, nos Estados Unidos. Disponível em: <http://www.loc.gov/teachers/tps/>. Acesso em: 28 out. 2014.
} 
Para a elaboração das narrativas, produziu-se uma seleção de aspectos históricos, os quais foram tratados segundo certo nível de aprofundamento. Esse nível pode ser alterado em intervenção didática com o uso das narrativas. Os riscos decorrentes de omissões realizadas pelos autores (ver seção anterior) devem ser observados pelo professor. Seu papel é fundamental no sentido de conduzir a discussão dos textos, esclarecer questões e lidar com possíveis efeitos das simplificações.

Se julgar adequado, em face ao seu contexto, o professor pode contornar eventuais dificuldades por meio de recursos adicionais. Pode recorrer a simulações gráficas a fim de facilitar a compreensão de determinados aspectos, como, por exemplo, as laçadas representativas de movimentos dos planetas.

Por decisão consciente dos autores, a redação dos textos é deficiente quanto ao detalhamento do contexto não científico. Utilizar trechos de filmes comerciais que fazem referência aos períodos históricos citados pode colaborar para que o aluno identifique melhor os contextos e situe temporalmente as discussões (ver, por exemplo, FORATO, 2009). Essa perspectiva vai ao encontro da legislação educacional, a qual sinaliza a relevância de enfatizar que o "surgimento de teorias Físicas mantém uma relação complexa com o contexto social em que ocorreram”. (BRASIL, 1999, p. 27).

Pode-se, em acompanhamento à utilização dos textos, recorrer a recursos do tipo "linha do tempo", inclusive na forma atividade interdisciplinar, em associação com o professor de História. No entanto, a utilização desse recurso demanda reflexão. A "linha" do tempo não deve transmitir a visão de que o conhecimento se constitui de forma linear, progressiva, em datas pontuais fixas. Muito pelo contrário, deve registrar controvérsias, rupturas e continuidades do processo de construção coletiva da ciência. É importante que esse caráter seja levado em conta e, inclusive, discutido com os alunos, os quais podem se envolver de forma ativa na elaboração de uma linha do tempo, buscando imagens e informações na internet.

Diversas atividades podem ser implementadas pelo professor em intervenções com o uso dos textos. Essas atividades podem envolver uma participação ativa dos estudantes: elaboração de histórias em quadrinhos, elaboração e encenação de peça teatral retratando aspectos que chamaram a atenção, realização de juris simulados, etc.

Sem exceção, a implementação de qualquer que seja a atividade ou recurso precisa ser bem refletida. Por exemplo, um júri simulado Heliocentrismo versus Geocentrismo, se realizado de forma descuidada, pode levar a vitórias simplistas de visões científicas próximas às atuais com base em avaliações anacrônicas de argumentos. Remontam a essa ponderação certos desafios da transposição didática da HC citados na literatura, como a dificuldade de tratar diacronicamente pensadores de épocas e culturas diferentes das nossas (FORATO, $2009)^{27}$.

\footnotetext{
${ }^{27}$ Exemplos de reflexões sobre as atividades citadas podem ser observadas em diversos trabalhos, tais como: GUERRA; REIS; BRAGA, 2002; FORATO, 2009; MEDINA; BRAGA, 2009; SILVA; MARTINS, 2009; MEDINA; BRAGA, 2010.
} 
Dessa forma, sustenta-se que informações e recursos adicionais podem ser relevantes se introduzidos de modo refletido. Atuando também numa etapa de transposição didática, é importante que o professor esteja atento quanto a evitar visões ingênuas sobre a ciência, distorções, pseudo-histórias e anacronismos.

\section{Considerações finais}

Questões como as debatidas nas seções anteriores são importantes para profissionais que vêm se dedicando a reflexões teóricas, elaboração de subsídios e materiais didáticos, bem como à realização de investigações empíricas sobre a implementação de propostas para a inserção da HFC no Ensino. As discussões sobre potencialidades, possibilidades e limitações das narrativas históricas podem contribuir para que formas de lidar com os desafios venham à tona.

Essas reflexões sugerem a necessidade de que as propostas para a inserção da HFC no Ensino sejam flexíveis, não "engessadas", adaptáveis a diferentes contextos educacionais. Considera-se aqui que a viabilidade de utilização de materiais como as narrativas históricofilosóficas está relacionada à sua própria flexibilidade, a qual precisaria ser apropriada de modo consciente pelo professor ${ }^{28}$.

Concebendo a inserção da HFC no Ensino como uma via de mão dupla, rechaça-se uma perspectiva equivocada de que ao professor caberia aplicar propostas, sem participar da (re) criação das mesmas. Iniciativas têm sido implementadas pelos pesquisadores no sentido de observar como as inovações curriculares têm chegado às escolas, o que implica a colaboração entre pesquisadores e professores, buscando superar a lacuna existente entre a pesquisa educacional e a prática docente ${ }^{29}$. Convém ressaltar, inclusive, que a utilização dos textos, em intervenções de diversas naturezas e em diferentes contextos de salas de aula, pode trazer à tona potencialidades e limitações que sequer foram previstas pelos autores, e podem eventualmente ser identificadas pelos próprios professores.

Refletir sobre esses aspectos colabora para que nos conscientizemos sobre o papel fundamental dos professores para a inserção da HFC no contexto da educação básica. Demanda atenção o fato de pesquisas empíricas demonstrarem que muitos docentes concebem a presença da HFC em sala de aula apenas como introdução de caráter motivador ou ilustrativa para os conteúdos científicos. A proposta efetiva de uma abordagem histórico-filosófica para conteúdos de ciência conflita com a perspectiva sustentada por parte significativa dos docentes (MARTINS, 2007).

\footnotetext{
${ }^{28}$ Vem se apontando na literatura a necessidade de convencê-los de que a inserção da HFC em suas aulas é benéfica e viável (HÖTTECKE; SILVA, 2011).

29 Iniciativas interessantes nesse sentido podem ser observadas. Ver, por exemplo, <http://www.bioemrede.ifba.edu.br/>. Acesso em: 11 jul. 2014.
} 
É importante lembrar ainda que mesmo professores que se interessam pela HFC no Ensino e compreendem a natureza dessa inserção, podem sustentar visões fragmentadas ou mal fundamentadas sobre a ciência. Portanto, sequências didáticas ou materiais inovadores que propõem problematizar visões ingênuas de ciência, não raro, trazem visões que se contrapõem ao que sustentam os próprios professores e materiais didáticos habituais (GIL PÉREZ et al., 2001, p. 128-129; FORATO; MARTINS; PIETROCOLA, 2012, p. 139).

No que se refere à atuação do professor para a inserção efetiva e consciente da HFC no contexto educacional devem ser levados em conta elementos formativos como: a necessidade de contato com exemplos de propostas didáticas de cunho histórico-filosófico para a abordagem de conteúdos de ciência e sobre a ciência; o desenvolvimento de competências que lhes permitam a adaptação de propostas aos seus contextos profissionais específicos.

Nesse sentido, ao discutir sobre potencialidades, possibilidades e limitações dos textos histórico-pedagógicos como abordagem para conteúdos de ciência e sobre a ciência, o presente artigo aponta elementos para a fundamentação do próprio professor, os quais precisam ser avançados. Procura-se, portanto, ir ao encontro do que vem apontando a literatura: "a validade de uma reflexão dos professores, devidamente apoiada" (GIL PÉREZ et al., 2001, p.128).

\section{Referências}

ALFONSO-GOLDFARB, A. M. O que é história da ciência. São Paulo: Brasiliense, 1994. $93 \mathrm{p}$.

BAGDONAS, A.; SILVA, C. C. Controvérsias sobre a natureza da ciência na educação científica. In: SILVA, C. C.; PRESTES, M. E. B. Aprendendo ciência e sobre sua natureza: abordagens históricas e filosóficas. São Carlos: Tipographia, 2013. p. 213-224.

BATISTA, R. P.; MOHR, A.; FERRARI, N. A análise da história da ciência em livros didáticos do ensino fundamental em Santa Catarina. In: ENCONTRO NACIONAL DE PESQUISA EM EDUCAÇÃO EM CIÊNCIAS, 6, 2007, Florianópolis, SC. Anais... ABRAPEC, 2007. Disponível em: <http://www.nutes.ufrj.br/abrapec/vienpec/CR2/p380.pdf>. Acesso em: 8 jul. 2014.

BIZZO, N. História da Ciência e Ensino: onde terminam os paralelos possíveis? Em aberto, Brasília, ano 11, n. 55, p. 29-35, jul/set.1992.

BRAGA, M. et al. Newton e o triunfo do mecanicismo. Col. Ciência no tempo. São Paulo: Atual Editora, 1999. 48 p.

BRASIL, Ministério da Educação - MEC, Secretaria de Educação Média e Tecnológica SEMTEC. Parâmetros Curriculares Nacionais para o Ensino Médio. Brasília: MEC/SEMTEC, 1999. 
CHALMERS, A. O que é ciência afinal? São Paulo: Editora Brasiliense, 1993. 224 p.

CLOUGH, M. P.; OLSON, J. K. Teaching and assessing the nature of science; an introduction. Science \& Education, Dordrecht, n. 17, p. 143-145, 2008.

COPÉRNICO, N. Commentariolus: Pequeno comentário de Nicolau Copérnico sobre suas próprias hipóteses acerca dos movimentos celestes. Tradução: Roberto de Andrade Martins. São Paulo: Editora Livraria da Física, 2003. 180 p.

DANIEL, G. P. História da ciência em um curso de licenciatura em Física: a gravitação newtoniana e a gravitação einsteiniana como exemplares. 2011. 404 f. Tese (Doutorado em Educação Científica e Tecnológica) - Programa de Pós-Graduação em Educação Científica e Tecnológica, UFSC, Florianópolis.

DRIVER, R.; OLDHAM, V. A. Constructivist approach to curriculum development in science. Studies in Science Education, Dordrecht, v. 13, p. 105-122, 1986.

FERREIRA, J. M. H. A resposta da astrologia à nova astronomia na Inglaterra do século XVII. Episteme, Porto Alegre, v. 29, p. 1-12, 2009.

FERREIRA, J. M. H. et al. Uma proposta do PIBID-Física da UFRN: abordagem históricofilosófica para a temática gravidade. In: SIMPÓSIO NACIONAL DE ENSINO DE FÍSICA, 20, 2013, São Paulo. Anais... SBF, 2013. Disponível em:

<http://www.sbf1.sbfisica.org.br/eventos/snef/xx/sys/resumos/T0874-1.pdf> . Acesso em: 28 de outubro de 2014.

FORATO, T. C. M. Os "poderes ocultos" da matéria e a gravitação universal. Edição especial Scientific American Brasil, São Paulo, v. 6, p. 38-43, 2006.

A natureza da ciência como saber escolar: um estudo de caso a partir da história da luz. 2009. 420 f. Tese (Doutorado em Educação) - Faculdade de Educação, USP, São Paulo.

FORATO, T. C. M.; MARTINS, R. A.; PIETROCOLA, M. Historiografia e Natureza da Ciência na sala de aula. Caderno Brasileiro de Ensino de Física, Florianópolis, v. 28, n. 1, p. 27-59, abr. 2011.

History and Nature of Science in High School: Building Up Parameters to Guide Educational Materials and Strategies. Science \& Education, Dordrecht, v. 21, p. 657-682, 2012. (a)

Enfrentando obstáculos na transposição didática da história da ciência para a sala de aula. In: PEDUZZI, L. O. Q.; MARTINS, A. F. P., FERREIRA, J. M. H. (Org.). Temas de história e filosofia da ciência no ensino. Natal: EDUFRN, 2012. cap. 5, p. 123-154. (b) 
FREIRE JR., O. ; MATOS FILHO, M.; DO VALLE, A. L. Uma explicação didática de como Newton apresentou a força gravitacional. A Física na Escola, São Paulo, v. 5, n. 1, p. 25-31, 2004.

GIL PÉREZ, D.; MONTORO, I. F.; ALIS, J. C.; CACHAPUZ, A.; PRAIA, J. Para uma imagem não deformada do trabalho científico. Ciência \& Educação, Bauru, v. 7, n. 2, p. 125$153,2001$.

GUERRA, A.; REIS, J. C.; BRAGA, M. Um julgamento no Ensino Médio: uma estratégia para trabalhar a ciência sob enfoque histórico filosófico. A Física na Escola, São Paulo, v. 3, n. 1, p. 8-11, mai. 2002.

HARRES, J. B. S. Concepções de professores sobre a natureza da ciência. 1999. Tese (Doutorado em Educação) - Faculdade de Educação, PUC-RS, Porto Alegre.

HÖTTECKE, D.; SILVA, C. C. Why Implementing History and Philosophy in School Science Education is a Challenge: An Analysis of Obstacles. Science \& Education, Dordrecht, v. 20, p. 293-316, 2010.

KOSMINSKY, L.; GIORDAN, M. Visões de ciências e sobre cientista entre estudantes do ensino médio. Química Nova na Escola, São Paulo, v. 15, s/n, p. 11-18, 2002.

LAKATOS, I. História da ciência e suas reconstruções racionais. Lisboa: Edições 70, 1998. 175p.

LEDERMAN, N. G. Student's and teacher's conceptions of the nature of science: a review of the research. Journal of research in Science Teaching, Michigan, v. 4, n. 29, p. 331-359, 1992.

Nature of science: past, present and future. In: ABELL, S.K.; LEDERMAN, N. G. (eds.). Handbook of Research on Science Education. Mahwah, New Jersey: Lawrence Erlbaum Publishers, 2007. cap. 28. p. 831-880.

Nature of scientific knowledge and scientific inquiry: building instructional capacity through professional development. In: FRASER, B. J.; TOBIN, K. J.; MCROBBIE, C. Second International Handbook of Science Education. Dordrecht, London: Springer, 2012. v. 1. p. 335-360.

LOPES, M. H. O. A retrogradação dos planetas e suas explicações: os orbes dos planetas e seus movimentos, da antiguidade a Copérnico. 2001. 232 f. Dissertação (Mestrado em História da Ciência). Programa de Pós-Graduação em História da Ciência, PUC, São Paulo.

MARTINS, R. A. Sobre o papel da história da ciência no ensino. Boletim da Sociedade Brasileira de História da Ciência, Rio de Janeiro, n. 9, p. 3-5, 1990. 
O Universo: teorias sobre sua origem e evolução. São Paulo: Editora Moderna, 1994.

História e História da Ciência: Encontros e Desencontros. In: CONGRESSO LUSOBRASILEIRO DE HISTÓRIA DA CIÊNCIA E DA TÉCNICA, 1, 2001, Évora. Actas... p. 11- 45. Disponível em: <http://www.ifi.unicamp.br/ ghtc/ups/pub/246.PDF>. Acesso em: 12 jul. 2014.

Ciência versus historiografia: os diferentes níveis discursivos nas obras sobre história da ciência. In: ALFONSO-GOLDFARB, A. M.; BELTRAN, M. H. R. (Eds.). Escrevendo a História da Ciência: tendências, propostas e discussões historiográficas. São Paulo: EDUC/Livraria de Física, 2005. cap. 5, p. 115-145.

Introdução. A história das ciências e seus usos na educação. In: SILVA, C. C. (Org.). Estudos de história e filosofia das ciências: subsídios para aplicação no ensino. São Paulo: Livraria da Física, 2006. p. xxi-xxxiv. (a)

A maçã de Newton: história, lendas e tolices. In: SILVA, C. C. (Org.). Estudos de história e filosofia das ciências: subsídios para aplicação no ensino. São Paulo: Livraria da Física, 2006. cap. IX, p. 167-189. (b)

MARTINS, A. F. P. História e filosofia da ciência no ensino: Há muitas pedras nesse caminho. Caderno Brasileiro de Ensino de Física, Florianópolis, v. 24, n.1, p.112-131, abr. 2007.

MATTHEWS, M. R. Science teaching: the role of History and Philosophy of Science. New York, London: Routledge, 1994. 287 p.

História, Filosofia e Ensino de Ciências: a tendência atual de reaproximação. Caderno Catarinense de Ensino de Física, Florianópolis, v. 12, n. 3, p. 164-214, 1995.

MCCOMAS, W. F.; ALMAZROA, H.; CLOUGH, M. The nature of science in science education: an introduction. Science \& Education, Dordrecht, v. 7, p. 511-532, 1998.

MCCOMAS, W. F. Seeking historical examples to illustrate key aspects of the nature of science. Science \& Education, Dordrecht, v. 17, p. 249-263, 2008.

MEDINA, M.; BRAGA, M. O teatro como ferramenta de aprendizagem da Física e de problematização da natureza da Ciência. Caderno Brasileiro de Ensino de Física, Florianópolis, v. 27, p. 313-333, 2010.

Oxigênio: Uma experiência educacional de História e Filosofia da Ciência no Teatro. Enseñanza de las Ciencias, v. extra, p. 317-320, 2009.

MELLO, A. D.; FIUZA, L.; GUERRA, A . O uso de imagens como um caminho capaz de problematizar questões a respeito da natureza da ciência em torno ao tema energia nuclear. In: 
ENCONTRO NACIONAL DE PESQUISA EM EDUCAÇÃO EM CIÊNCIAS, 9, 2013, Águas de Lindóia. Anais... ABRAPEC, 2013. Disponível em:

$<$ http://www.nutes.ufrj.br/abrapec/ixenpec/atas/resumos/R0250-1.pdf>. Acesso em: 7 jul. 2014.

OLIVEIRA, F. F.; GUERRA, A. Controvérsia histórica: uma possibilidade para problematização a respeito de aspectos de natureza da ciência. In: ENCONTRO NACIONAL DE PESQUISA EM EDUCAÇÃO EM CIÊNCIAS, 9, 2013, Águas de Lindóia. Anais... ABRAPEC, 2013. Disponível em: <http://www.nutes.ufrj.br/abrapec/ixenpec/atas/resumos/R0450-1.pdf>. Acesso em: 7 jul. 2014.

PAGLIARINI, C. R.; SILVA, C. C. A estrutura dos mitos históricos nos livros de Física. In: ENCONTRO DE PESQUISA EM ENSINO DE FÍSICA, 10, 2006, Londrina, PR. Disponível em: <http://www.ifsc.usp.br/ cibelle/arquivos/T0124-1.pdf>. Acesso em: 8 jul. 2014.

PEDUZZI, L. O. Q. Sobre a utilização didática da História da Ciência. In: PIETROCOLA, M. (Org.). Ensino de Física: conteúdo, metodologia e epistemologia numa concepção integradora. Florianópolis: Ed. da UFSC, 2001. cap. 7. p. 151-170.

Força e movimento: de Thales a Galileu. Florianópolis, 2008. Material instrucional utilizado na disciplina Evolução dos Conceitos da Física do curso de Física da UFSC. Disponível em:

<http://www.if.ufrgs.br/ lang/Textos/Textos_Peduzzi/For\%E7a\%20e\%20movimento\%20$\% 20 \mathrm{de} \% 20$ Thales\%20a\%20Galileu.pdf>. Acesso em: 28 out. 2014.

PENA, F. L. A.; TEIXEIRA, E. S. Parâmetros para avaliar a produção literária em História e Filosofia da Ciência voltada para o ensino e divulgação das ideias da Física. Caderno Brasileiro de Ensino de Física, Florianópolis, v. 30, n. 3, p. 471-491, 2013.

RIBEIRO, R. M. L.; MARTINS, I. O potencial das narrativas como recurso para o ensino de ciências: uma análise em livros didáticos de Física. Ciência \& Educação, Bauru, v. 13, n. 3 , p. 293-309, 2007.

ROBILOTTA. O cinza, o branco e o preto: da relevância da história da ciência no ensino da Física. Caderno Catarinense de Ensino de Física, Florianópolis, v. 5, n. 5, p. 7-22, 1988.

SILVA, B. V. C. E. ; MARTINS, A. F. P. Júri simulado: um uso da história e filosofia da ciência no ensino da óptica. A Física na Escola, São Paulo, v. 10, p. 17-20, 2009.

SILVA, C. C.; MOURA, B. A. A natureza da ciência por meio do estudo de episódios históricos: o caso da popularização da óptica newtoniana. Revista Brasileira de Ensino de Física, São Paulo, v. 30, n. 1, p. 1602-1610, 2008. 
SILVEIRA, F. L.; PEDUZZI, L. O. Q. Três episódios de descoberta científica: da caricatura empirista a uma outra história. Caderno Brasileiro de Ensino de Física, Florianópolis, v. 23, n.1, p. 26-52, 2006.

TEIXEIRA, E. S.; EL-HANI, C. N.; FREIRE JUNIOR. O. Concepções de estudantes de Física sobre a Natureza da Ciência e sua transformação por uma abordagem contextual do Ensino de Ciências. Revista Brasileira de Pesquisa em Educação em Ciências, São Paulo, v. 1, n. 3, p. 111-123, 2001.

TEIXEIRA, E. S.; GRECA, I. M.; FREIRE JR, O. Uma revisão sistemática das pesquisas publicadas no Brasil sobre o uso didático de História e Filosofia da Ciência no ensino de Física. In: PEDUZZI, L. O. Q.; MARTINS, A. F. P., FERREIRA, J. M. H. (Org.). Temas de história e filosofia da ciência no ensino. Natal: EDUFRN, 2012. cap. 1. p. 9-40.

VIDEIRA, A. A. P. Historiografia e história da ciência. Escritos (Fundação Casa de Rui Barbosa), Rio de Janeiro, v. 1, p. 111-158, 2007.

VITAL, A.; GUERRA, A. A natureza da ciência no ensino de Física: estratégias didáticas elaboradas por professores egressos do mestrado profissional. Caderno Brasileiro de Ensino de Física, Florianópolis, v. 31, n. 2, p. 225-257, ago. 2014.

WESTFALL, R. S. A construção da ciência moderna: mecanismos e mecânica. Porto: Porto Editora, 2003. $176 \mathrm{p}$.

\section{Apêndice 1 - Texto "Laçadas no céu"}

Há muito tempo atrás, na Antiguidade, pensadores gregos propunham explicações para fenômenos da natureza. As explicações podiam ser distintas e até mesmo a forma de produzir conhecimento podia variar de acordo com a corrente filosófica da qual participavam. Alguns diziam que os sentidos não eram confiáveis, produzindo impressões falsas. Apenas a razão seria confiável para refletir sobre fenômenos como movimento, som e luz. Outros diziam que podiam confiar nas evidências sensoriais, como no que ouviam e viam, por exemplo.

Fizeram longas observações do céu, registrando as posições das estrelas pacientemente noite após noite. Perceberam, então, estrelas que ficavam fixas, formando desenhos permanentes no céu. Algumas outras estrelas mudavam de posição ao longo do ano, como se vagassem em meio aos desenhos. Chamaram essas outras estrelas de "planetas", o que significa "errante". Esse movimento visto da Terra podia ser mesmo muito estranho.

Quem observa ao longo do ano os movimentos de alguns planetas nota que eles parecem fazer "laçadas no céu". Podemos ver abaixo esse tipo de movimento para Marte. Ele faz o que na Antiguidade chamaram de "retrogradação", isto é, vai e depois volta. 


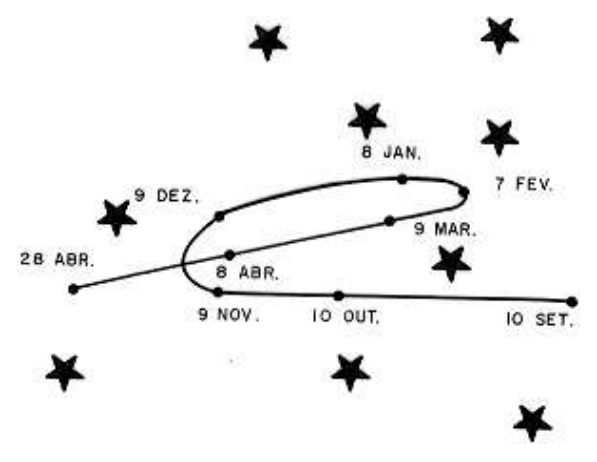

Fig. 1 - Registro do movimento de Marte.

Observar esse movimento tão estranho dos planetas podia ser um problema para certos pensadores dependendo do contexto cultural do qual participavam. Alguns consideravam que os astros eram perfeitos e deveriam ter movimentos perfeitos, ou seja, circulares. Isso porque, para eles, o círculo era a forma perfeita, sem início, nem fim. Até hoje, essa ideia está presente quando usamos alianças de casamento que simbolizam o amor sem fim.

Voltando àqueles pensadores... para eles, então, os planetas não poderiam ter movimentos esquisitos como laçadas, embora fosse isso o que viam da Terra.

$\mathrm{O}$ que fazer então? Essa parece ser a pergunta que fizeram e deve ter sido mesmo muito complicado enfrentá-la.

Propuseram vários tipos de modelos para tentar conciliar seus pressupostos teóricos (planetas devem percorrer círculos) ao que pareciam observar (planetas fazem laçadas no céu).

Uma das soluções encontradas foi usar uma composição de círculos que, em conjunto, "produziam" as laçadas e explicavam o movimento de cada planeta visto da Terra.

Essa ideia estava presente no sistema Geocêntrico proposto pelo filósofo grego Aristóteles no século IV a.C. O nome "Geocêntrico" indicava que os corpos celestes giravam em torno da Terra.

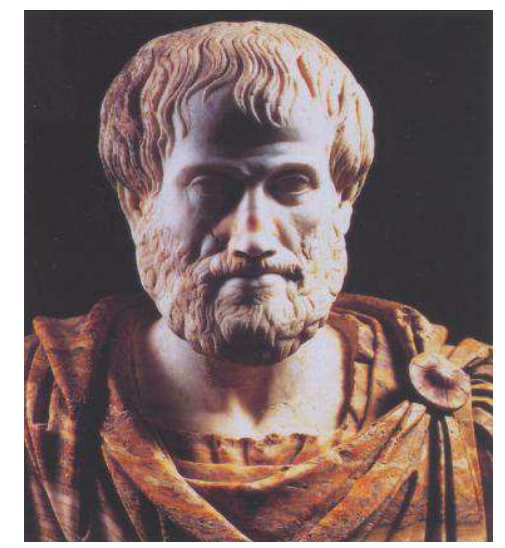

Fig. 2 - Imagem de Aristóteles.

Esse sistema Geocêntrico foi bem aceito. Ganhou modificações importantes desde a época de Aristóteles, já que os astrônomos buscavam uma descrição ainda mais precisa dos movimentos dos corpos celestes.

Entre esses astrônomos, Cláudio Ptolomeu, no século II (já depois de Cristo) foi um dos mais importantes. Assim, o "modelo aristotélico" passou a ser conhecido como "modelo aristotélico-ptolomaico".

Nesse modelo, a Terra ficava parada no centro do mundo. Em sequência vinham Lua, Mercúrio, Vênus, Sol, Marte, Júpiter e Saturno movendo-se ao seu redor. Depois de tudo vinha o firmamento, onde as estrelas estavam fixas. 
O Sol e a Lua descreviam círculos em torno da Terra. Para explicar o movimento dos outros planetas, que davam laçadas, era preciso usar uma composição de círculos, e, dessa forma, epiciclos e deferentes formavam um modelo sofisticado.

Só uma correção antes de continuarmos... Também para dar conta de forma mais precisa dos movimentos observados, esse modelo tinha algumas outras sofisticações. A Terra não estava exatamente no centro, mas sim meio deslocada. Assim, o sistema elaborado não deveria ser chamado de Geocêntrico. Era Geostático, já que a Terra estava parada, mas não Geocêntrico.

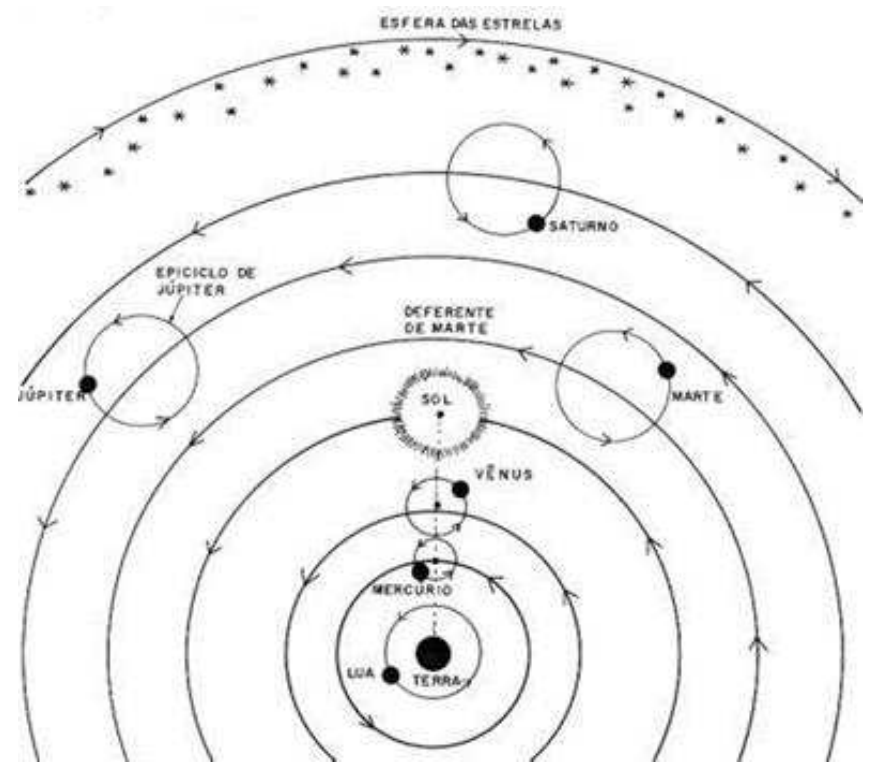

Fig. 3 - Ilustração de sistema Geocêntrico.

No entanto, é como Geocêntrico que costumamos conhecê-lo, não é? Então, vamos dizer Geocêntrico, mas lembrando que isso é algo aproximado.

Esse tipo de sistema era relacionado à Física que havia sido proposta por Aristóteles vários séculos antes. Ou melhor, às duas Físicas estabelecidas por ele.

Da Lua para cima, isto é, no "mundo supralunar", nada mudava. Tudo era permanente, perfeito e formado pelo éter, o elemento imutável. Nesse mundo, os corpos tinham movimentos circulares naturais. Havia uma Física com características próprias para esse mundo.

Havia uma outra Física para o chamado "mundo sublunar", isto é, para o que estava da Terra até a Lua. Nesse mundo tudo era formado por apenas quatro elementos: fogo, terra, ar e água. Esse era o lugar das mudanças, onde as coisas nasciam, cresciam, morriam, eram modificadas.

Nesse mundo, os corpos chamados "graves" (como uma pedra, uma caneta, etc.) caíam para a Terra porque eles buscavam seu lugar natural. Tentavam retornar ao centro do universo, onde estava a Terra. Esses corpos tinham a propriedade de Gravidade.

A Terra ficava parada no centro. Aristóteles dizia, por exemplo, que quando jogamos uma pedra do alto de uma torre ela cai no pé da torre justamente porque a Terra está parada. Afinal, se o chão se movesse, a torre seguiria com o chão... e a pedra que havia ficado no ar cairia afastada do pé da torre. Como isso não ocorria, a Terra devia estar parada.

Então, resumindo, o mundo era Geocêntrico, isto é, com a Terra (aproximadamente) no centro e parada. Os corpos caíam para baixo porque possuíam Gravidade. 
Esse modelo Geocêntrico aristotélico-ptolomaico e toda a Física relacionada a ele eram bem aceitos quando os portugueses chegaram ao Brasil, em 1500.

Mas... o que será que aconteceu depois ? Será que aceitamos esse modelo hoje? E a Física... existem duas? É assim ou mudou?

Fig. 1 - Disponível em: <http://www.oba.org.br/cursos/astronomia/fundamentoshistastro.htm>. Acesso em: 11 jul. 2014.

Fig. 2 - Disponível em: <http://www.ghtc.usp.br/server/Sites-HF/Paula-Sampaio2/>. Acesso em: 11 jul. 2014.

Fig 3 - Disponível em:<http://www.oba.org.br/cursos/astronomia/fundamentoshistastro.htm>. Acesso em: 11 jul. 2014.

\section{Apêndice 2 - Texto "Heliocentrismo versus Geocentrismo"}

No texto passado vimos que, no século IV a. C., o filósofo Aristóteles chamava de "graves" os corpos que caíam quando eram soltos no ar. Eles caíam porque buscavam o centro do universo. Então, como os corpos caíam para a Terra, Aristóteles concluiu que ela estava no centro do universo.

A “queda dos corpos graves" era, então, um argumento a favor do geocentrismo. Era importante para o sistema aristotélico-ptolomaico que, no texto passado, dissemos que era o mais aceito no início do século XVI, quando os portugueses chegaram ao Brasil.

E foi justamente nessa época que o pensador Nicolau Copérnico propôs um sistema de mundo Heliocêntrico, isto é, com o Sol no centro do universo. Copérnico utilizou dados muito precisos. Não se baseou em novas informações da astronomia, muito menos no uso do telescópio, que só surgiu bem depois de sua morte...

A motivação de Copérnico era pensar que se o Sol era "fonte da vida" deveria ficar no centro. Em seguida, viriam Mercúrio, Vênus, Terra, Marte, Júpiter e Saturno. Manteve os planetas em órbitas circulares, seguindo o mesmo ideal de perfeição da Antiguidade. A fim de dar conta do que se observava, precisou manter também a composição de círculos, recorrendo a epiciclos e deferentes. Assim, a ilustração trazida na Figura 2 é uma simplificação. Ela não mostra toda a complexidade do sistema de Copérnico, que tinha recursos semelhantes aos de Ptolomeu.

Copérnico morreu no mesmo ano em que suas ideias foram publicadas, e várias questões foram surgindo... Como explicar a queda dos corpos? Se para Aristóteles eles caíam porque buscavam o centro do universo onde estava a Terra... e quando se propunha tirar a Terra do centro, colocando o Sol nesse lugar? Por que os corpos caíam para a Terra e não para o Sol?

Explicar a "queda dos corpos" tornou-se um problema para quem defendia o heliocentrismo. Aliás, quem gostou do sistema de Copérnico tinha que lidar ainda com muitos outros problemas. Um deles era o "argumento da torre". 


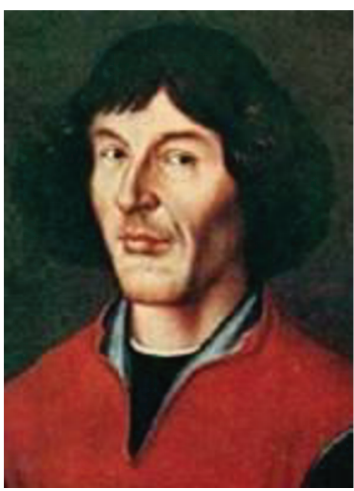

Fig. 1-Nicolau

Copérnico.

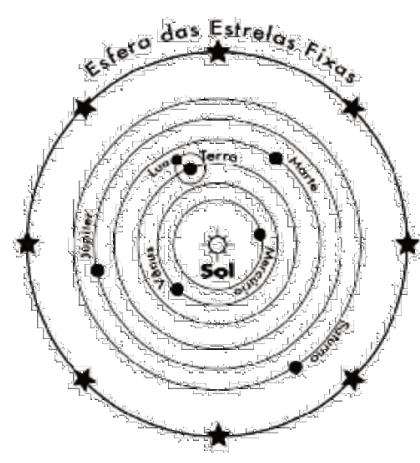

Fig. 2 - Ilustração de sistema Heliocêntrico.

Como dissemos no texto passado, para o filósofo Aristóteles, quando uma pedra caía do alto de uma torre, ela caía no pé da torre justamente porque a Terra estava parada.

Esse argumento chamado de "argumento da torre" era usado, então, para mostrar que a Terra estava parada. Foi repetido, repetido... e continuava com força total lá no século XVI quando o sistema Heliocêntrico surgiu dizendo que a Terra estava em movimento. Então, quem aceitava o novo sistema precisava derrubar esse argumento...

Quem resolveu esse problema? Galileu Galilei era adepto do sistema de Copérnico e resolveu colaborar para a solução desse problema. Precisou da ajuda de muitos pensadores... Sem as ideias do próprio Aristóteles, de muitos pesquisadores da Idade Média e de seus contemporâneos, ele possivelmente não chegaria a lugar algum. Ciência não se faz sozinho, nem de uma hora para outra.

Foi, então, com muito estudo do que outros haviam dito que Galileu concluiu que a pedra cairia no pé da torre em qualquer situação: tanto se a Terra estivesse parada ou em movimento. Para convencer as pessoas sobre isso, ele lembrou o seguinte: se estamos na cabine fechada de um navio gotas d'água pingam dentro de um vaso da mesma forma quer o barco esteja em movimento ou parado. Ele citou muitos fenômenos para mostrar que qualquer coisa que ocorra na cabine não nos permite dizer se o navio está ou não em movimento.

O recado de Galileu era o seguinte: o "argumento da torre" não mostra que a Terra está parada; era possível sim aceitar o sistema Heliocêntrico, no qual a Terra estava em movimento. Como dá para perceber havia, então, na época de Galileu uma briga feia entre copernicanos (heliocentristas) e aristotélicos (geocentristas).

O que estava sendo observado pela astronomia podia até ajudar quem preferia o sistema Heliocêntrico...

No texto passado, vimos que Aristóteles dividia o mundo em sublunar, onde tudo era imperfeito e mudava, e supralunar, onde tudo era perfeito e constante. Mas, a astronomia dos séculos XVI e XVII parecia sugerir que isso não era bem assim.

Vamos a dois exemplos importantes que sugeriam mudanças e imperfeições também no mundo supralunar. Dentre muitas outras contribuições suas importantes, o astrônomo Tycho Brahe realizou observações a olho nu e notou que estrelas mudavam. Podiam nascer e morrer. Com o telescópio, Galileu obteve imagens que interpretou como crateras e montanhas na Lua e manchas no Sol. Mas nem todo mundo aceitava o uso do telescópio e havia motivo para isso. Nem se sabia muito bem como ele funcionava. Quem sabe o instrumento moderno 
não estava criando deformações que não existiam? Essa hipótese foi mesmo cogitada na época.

De qualquer forma, o que Galileu e Brahe diziam abalava o que então era aceito: talvez o mundo supralunar não fosse tão perfeito nem tão constante quanto Aristóteles pensava.

O sistema Heliocêntrico podia acabar com a diferença entre sublunar e supralunar. Isso criaria um problemão para a Ciência da época: o que fazer com as duas Físicas que existiam? Lembrando o que vimos no texto passado, havia, então, uma Física para o mundo sublunar e outra para o supralunar...

Fig. 1 - Disponível em:

$<$ http://www.histedbr.fae.unicamp.br/navegando/glossario/verb_b_nicolau_copernico.htm>. Acesso em: 11 jul. 2014.

Fig. 2 - Disponível em: <http://www.if.ufrgs.br/tex/fis01043/20041/Diomar/sistema_solar.html>. Acesso em: 11 jul. 2014.

\section{Apêndice 3 - "Uma nova proposta sobre a Gravidade"}

Vimos no texto passado que os copernicanos (heliocentristas) tiveram alguns problemas para enfrentar. O "argumento da torre" foi um deles.

A necessidade de uma Física compatível com o modelo Heliocêntrico foi outro. Nesse modelo não fazia sentido dividir o mundo em sublunar e supralunar. Além disso, as observações astronômicas indicavam que tudo era muito parecido. Se não havia dois mundos distintos, não havia sentido que existissem duas Físicas diferentes, como se pensava na Antiguidade.

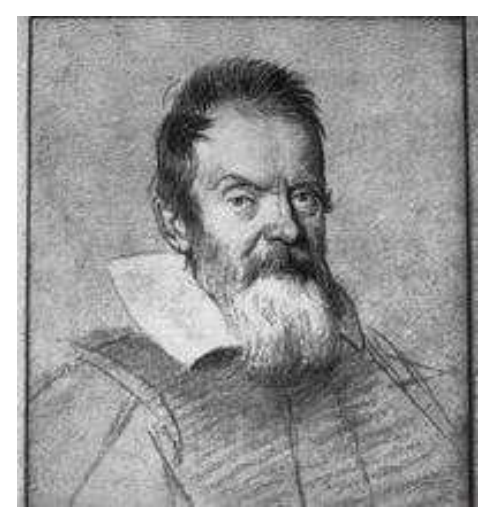

Fig. 1 - Galileu Galilei.

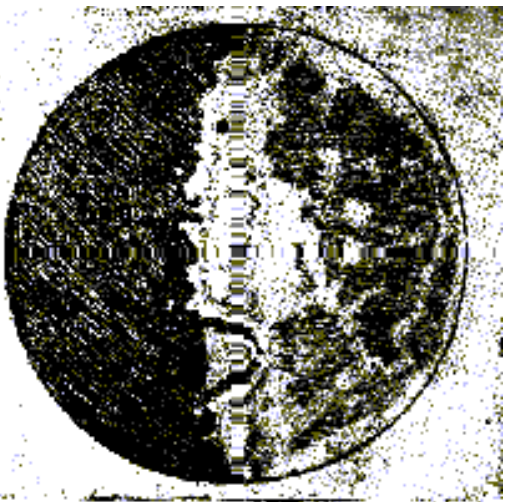

Fig. 2 -Desenho da Lua realizado por Galileu.

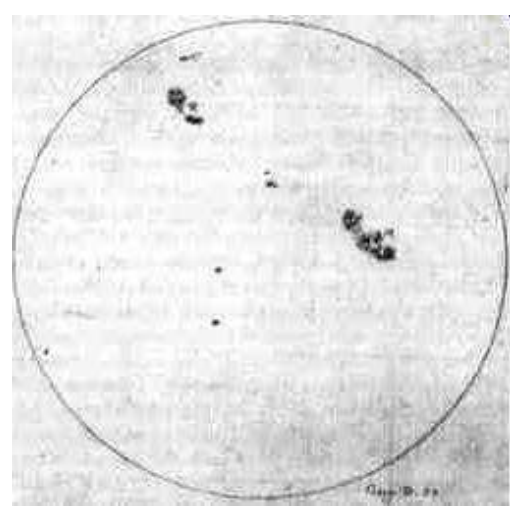

Fig. 3 - Desenho do Sol realizado por Galileu.

A "unificação da Física" ocorreu aos poucos, na época em que viveram personagens como René Descartes, Galileu Galilei e Isaac Newton. Essa unificação se relacionou a 
certos conhecimentos como uma nova compreensão do que seriam os movimentos dos corpos e a um novo entendimento sobre Gravidade.

Como vimos, na Antiguidade, considerava-se que a Gravidade era uma propriedade dos corpos graves. Eles buscavam o centro do universo, no qual estava a Terra. Não eram atraídos por ela.

Quase dois mil anos depois de Aristóteles, René Descartes, um pensador francês adepto do heliocentrismo, propôs outra explicação. Para Descartes, os corpos caíam porque eram empurrados em direção a Terra por uma correnteza de um elemento invisível, o éter. Isso foi no século XVII. Havia, portanto, certo contexto de questionamento à visão de Gravidade como propriedade de um corpo.

O pensador inglês Isaac Newton estava inserido nesse contexto de rejeição à Gravidade aristotélica. Newton aceitava a nova explicação proposta por Descartes para a Gravidade quando, ainda jovem, resolver estudar mais sobre esse assunto. Depois de muitas leituras, estudos e reflexões, acabou mudando de ideia.

Foi muito importante para Newton uma ideia que havia sido proposta pelo filósofo Francis Bacon alguns anos antes: a Gravidade deveria diminuir com a altura. Então, quanto mais distante da Terra, menor a tendência apresentada pelo corpo grave.

Com base nessa proposta, Newton pode ter pensado... se a Gravidade diminui com a altura, até onde será que ela chega? Será que ela chega até a Lua? Vamos deixar essa pergunta aí parada um pouquinho...

Naquela mesma época, Descartes havia estudado o movimento circular de uma pedra amarrada num cordão seguro por uma pessoa. O que impedia que a pedra escapasse, nesse caso, era o puxão que a pessoa dava, mantendo a pedra na sua trajetória.

Newton sabia desse estudo de Descartes, que o ajudaria muito a resolver uma questão importante. Se a Lua se movia em torno da Terra, algo deveria manter a Lua nessa trajetória, sem deixar que ela escapasse... Era como se a Lua fosse escapar da sua trajetória, mas algo sempre a puxasse em direção à Terra, mantendo o seu movimento.

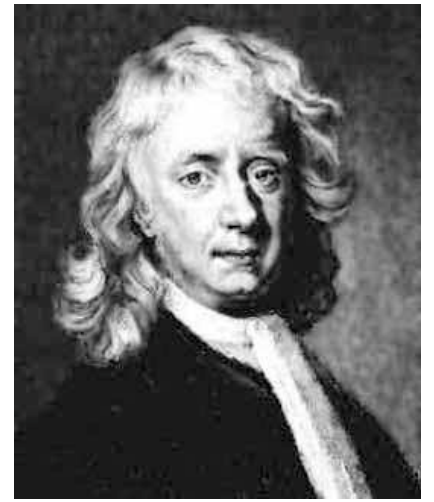

Fig. 4-Isaac Newton.

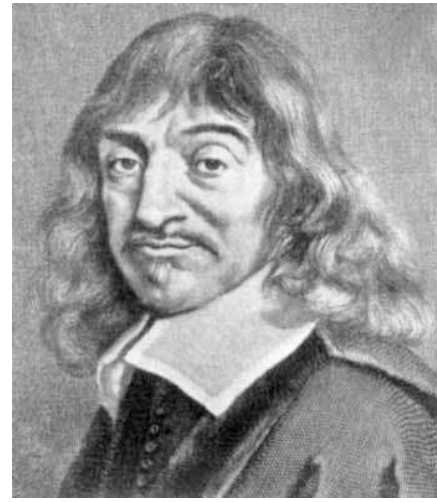

Fig. 5 - René Descartes

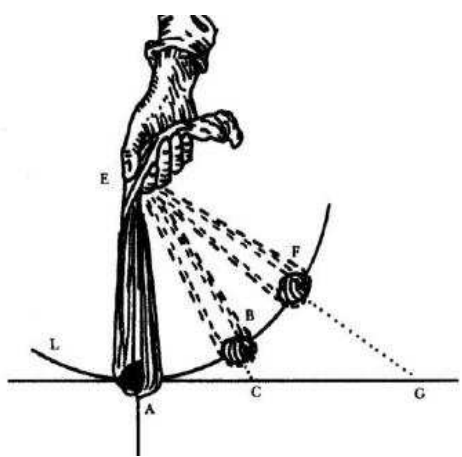

Fig. 6-Representação para o movimento da pedra amarrada. 
Voltando, então, àquela pergunta..., Newton usou os resultados dos estudos de Descartes. Newton pensou que a força da Gravidade agia à distância sobre a Lua, tal como a mão da pessoa que puxava a pedra amarrada. Depois de muito esforço e cálculos complicados, ele propôs o seguinte: a força da "Gravidade" que atraía para a Terra uma maçã solta no ar era justamente a força que mantinha a Lua em seu movimento, fazendo com que ela sempre "caísse" em direção a Terra e não saísse pela tangente à sua trajetória. Essa força, segundo os cálculos de Newton, era proporcional ao inverso do quadrado da distância entre os corpos.

O que Newton estava dizendo representava uma mudança muito grande no modo como se compreendia a Gravidade. Ela não era mais uma propriedade do corpo. Passava a ser, então, uma força que agia a distância sobre um corpo. Para propor isso, Newton precisou muito da colaboração da Alquimia que ele há muito tempo estudava. A Alquimia aceitava ação à distância, mas a Física da época de Newton não.

A proposta de Newton ajudou a unificar a Física, pois algo que acontecia na Terra (queda de uma maçã, por exemplo) e com a Lua (seu movimento em torno da Terra) poderia ser explicado da mesma forma. Newton foi mais além nessa unificação, algum tempo depois, quando tentou responder a uma questão importante naquela época.

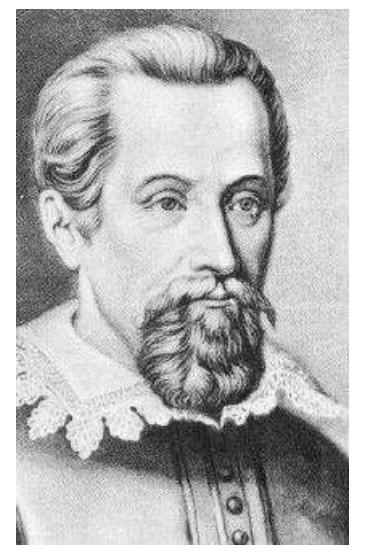

Fig. 7- Johannes Kepler.

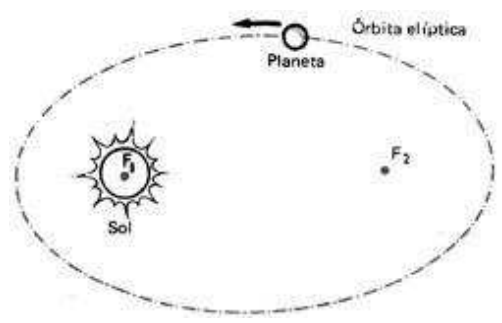

Fig. 8 - Órbita elíptica.

O astrônomo Johannes Kepler havia percebido que o sistema de Copérnico com as órbitas circulares não dava muito certo. As trajetórias dos planetas não podiam ser explicadas assim. Kepler propôs, então, que as órbitas fossem elípticas, com o Sol em um dos focos.

Mas que tipo de força poderia manter os planetas nesse tipo de trajetória? Newton realizou cálculos a respeito desse problema e chegou à conclusão de que uma força atrativa entre o Sol e o planeta, proporcional ao inverso do quadrado da distância entre eles, daria esse resultado.

Então, sua conclusão foi que todos os corpos se atraíam segundo essa relação. A chamada "Gravitação Universal” abriu caminho para a consolidação de uma Física unificada.

Dá para perceber, assim, que todo esse conhecimento não dependeu somente de uma pessoa e não apareceu de repente, mas sim com muito estudo e cooperação. Achar que uma 
maçã caiu na cabeça de alguém e aí tudo foi entendido por ele, sozinho, rapidamente... não dá, não é?

Fig. 1 - Disponível em: <http://www.cienciamao.usp.br/viagensespaciais/index.php?painel=07>. Acesso em: 10 jul. 2014.

Fig. 2 - Disponível em: <http://plato.if.usp.br/1-2003/fmt0405d/apostila/renasc7/node6.html>. Acesso em: 10 jul. 2014.

Fig. 3 - Disponível em: <http://www.horaultima.decoelum.net/portugues/Sol.html>. Acesso em: 10 jul. 2014.

Fig. 4 - Disponível em: < http://ecalculo.if.usp.br/historia/newton.htm>. Acesso em: 11 jul. 2014.

Fig. 5 - Disponível em: <http://ecalculo.if.usp.br/historia/newton.htm>. Acesso em: 11 jul. 2014.

Fig. 6 - Disponível em: < http://www.ghtc.usp.br/server/pdf/RAM-livro-Cibelle-Newton.pdf>. Acesso em: 10 jul. 2014.

Fig. 7 - Disponível em:< http://astro.if.ufrgs.br/bib/bibkepler.htm>. Acesso em: 11 jul. 2014.

Fig. 8 - Disponível em: <http://www.colegioweb.com.br/trabalhos-escolares/fisica/dinamica/as-leis-dekepler.html>. Acesso em: 11 jul. 2014. 